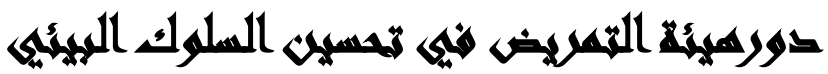

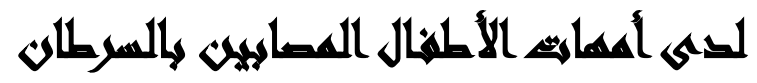

رضا محمد محمود طنطاوى(')- محمد رذق البحيرى (ץ)- مديحة أمين مرسى (r)

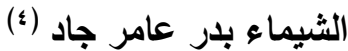

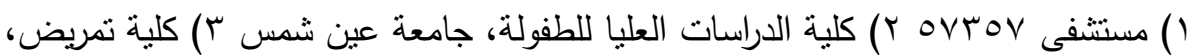

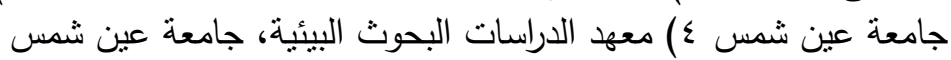

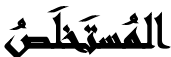

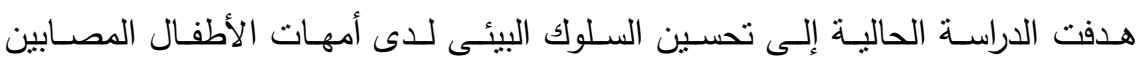

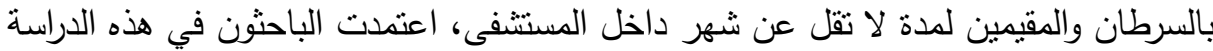

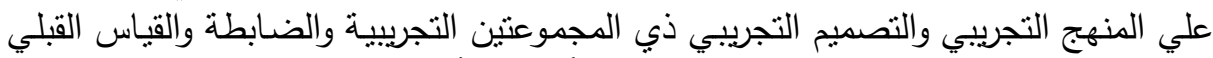

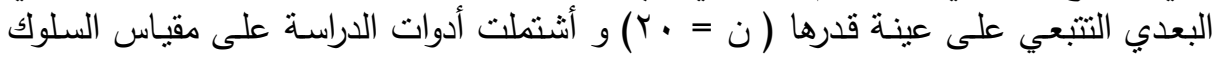

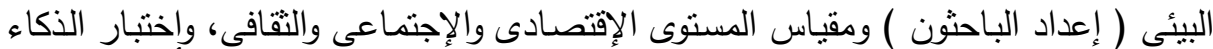

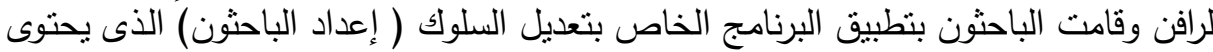

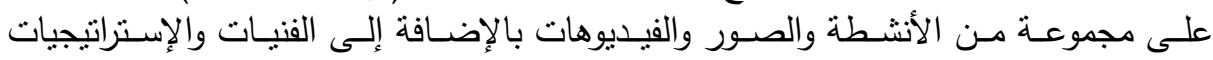
الخاصة بالبرنامج على المجموعة التجريبية، واستغرق تطبيق البرنامئامج شهرين. وكانت اهم النتائج التى توصلت لها لها الدراسة كالآتى:

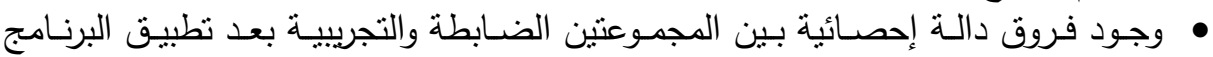

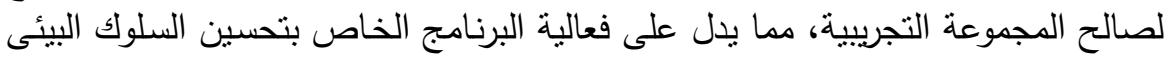

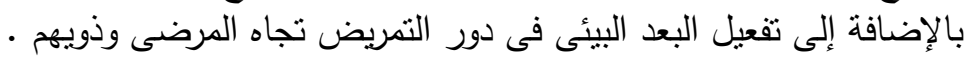

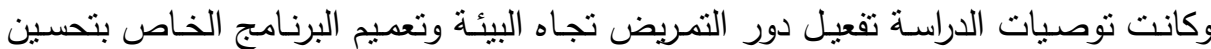

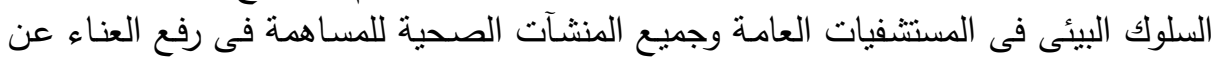

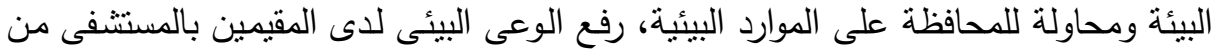

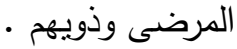

$$
\begin{aligned}
& \text { المجلد التاسع والأربعون، العدد الثاني عشر، جزء (0) ديسمبر •.r.r. }
\end{aligned}
$$

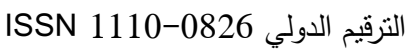


مجلة العلوم البيئية

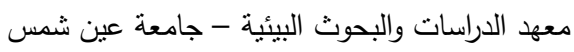

رضا محمد محمود طنطاوى وآخرون

\section{Xaxid}

لقد إحتلت القضايا البيئية محل الصدراة فى مقدمة المشكلات سواء الدولية أوالعالمية التى تحتـاج إلى الدراسـة والتحليل والوصسول إلى الحلـول الفعالـة وقد عقدت عدة مـؤتمرات للوصل إلى حلول فعالة ووضع القوانين الدولية للمحافظة على البيئة .

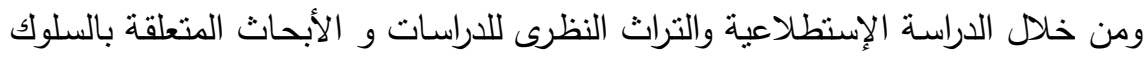

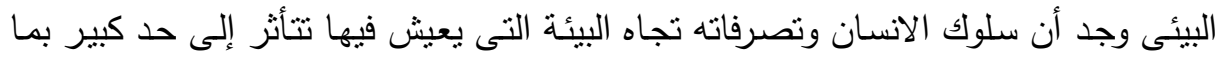

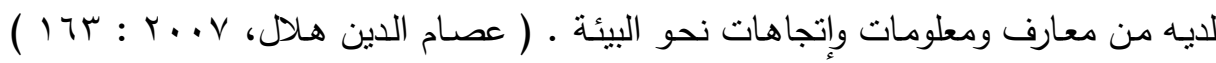
وإن تغيير هذه السلوكيات لا يتم عن طريـق القوانين والتتـريعات ولكن مـن خـلال التتشئة

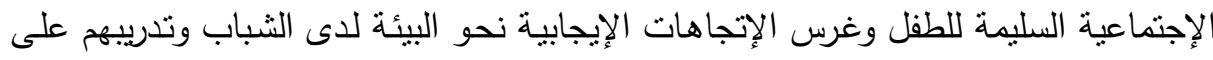
التعامل الرشيد مـع الموارد البيئية، ويمكن تعديل السلوكيات السلبية عن طريق التعديل فى التي

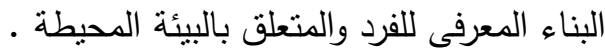
ونظرا لإرنباط السلوكيات البيئية بـالتلوث البيئى الذى أحدثه الإنسان سعياً وراء التقدم

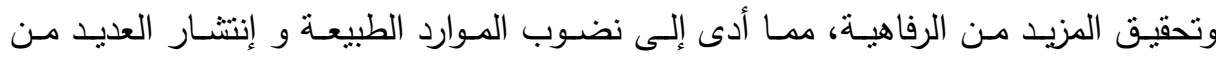

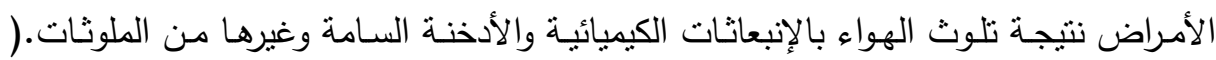

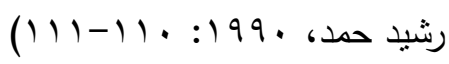

ونظرا للدور الحيوى لهيئة التمريض فى التعامل مـع المرضى وتقديم الرعاب الصحية

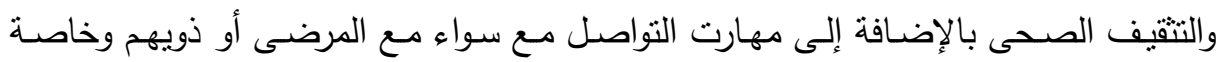

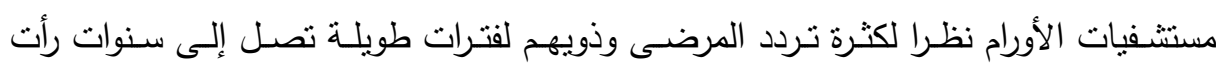

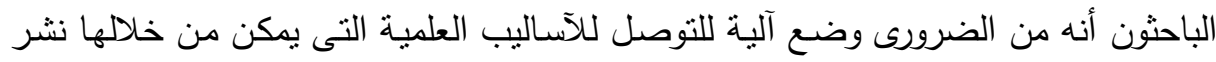

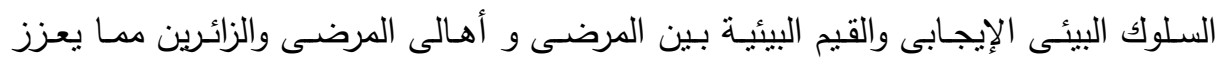

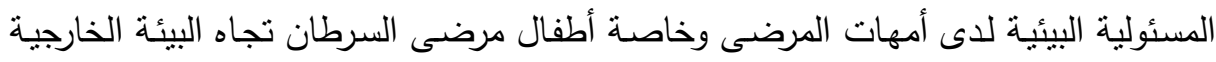

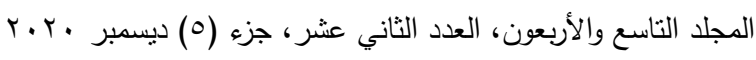

$$
\begin{aligned}
& \text { التزقيم الدولي 0826-1110 الاني }
\end{aligned}
$$


و لقد أثتبت الدراسات الخاصة بالسلوك البيئى أن خرق قانون أو عرف بيئى لأى مكان

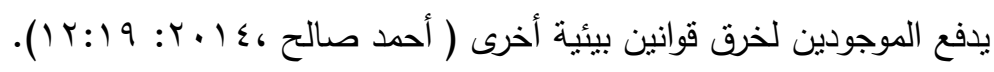

\section{Anthan}

أمام تتامي الاهتمام بالأمور البيئية وبروز مفهوم التتمية المستدامة وجدت المؤسسات نفسها أمام واقع يحتم عليها تحمل المسؤولية تجاه البيئية، لما تسببه من أضرار عند التهد ممارستها لنشاطها. وأصبحت هذه المؤسسات تخضـع لضغوطات متتامية من قوانين وتشريعات بيئية ومنظمـات مهنيـة، مها دفع العديد منها لإدمـاج البعد البيئي ضمن سياسـاتها واستراتيجياتها

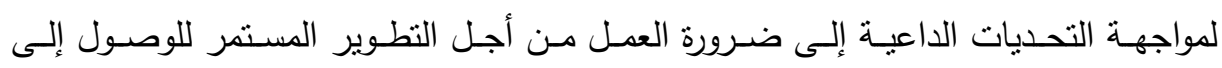

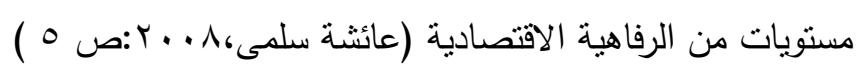

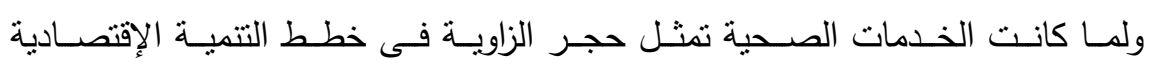
والإجتماعية، فإن مهنة التمريض تعد من المهن النبيلة فى حياة البشرية و أقدمها حيث يعتبر تاريخ هذه المهنة ناريخ كفاح للأمراض التى تتعرض لهار التها البشرية، والذين حملوا على عاتقهم

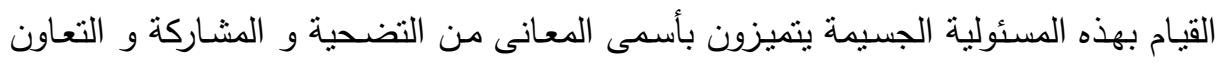

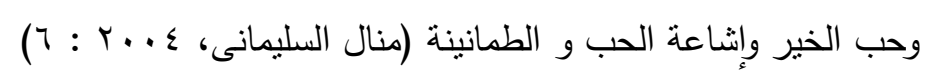
ولكى تتم عملية تحسين السلوك فإنه يتم تحديد السلوك الهادف الإيجابى المرغوب والمراد تحقيقه في نهاية برامج تعديل السلوك، من خلال تحديد الأهداف السلوكية، أو السلوك النهائي

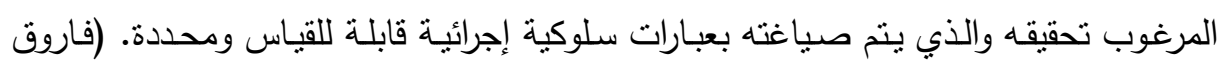

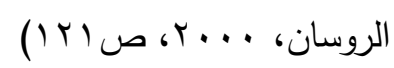
وهنا تم طرح السؤال والافتراض فى امكانية مساهمة التمريض فى تحسين السلوك البيئى

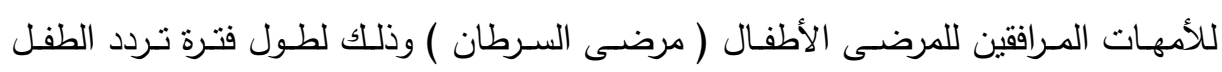

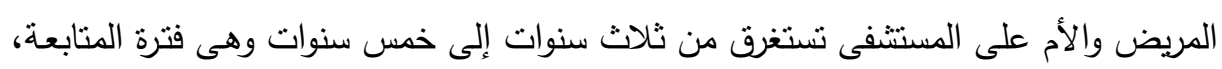

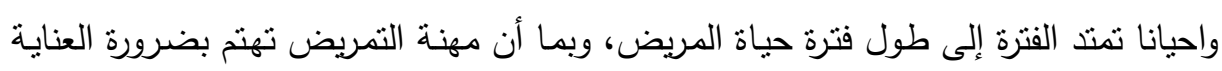

$$
\begin{aligned}
& \text { r.r. المجلد التاسع والأربعون، العدد الثاني عثر، جزء (0) ديسمبر } \\
& \text { التزقيم الدولي 0826-08 1110 }
\end{aligned}
$$


بالسليم والمريض والمعاق على حد سواء جسمانيا وعقليا ونفسيا، وأصبح جهاز التمريض

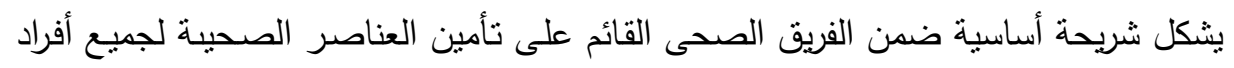

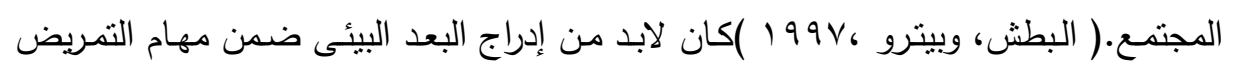

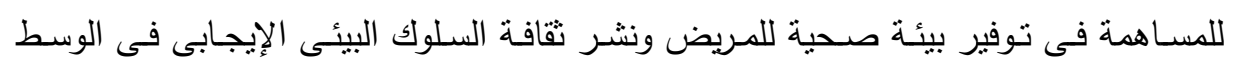
المحيط للحد من السلوكيات السلبية المضرة بالبيئة.

\section{أسريلة الهيهA}

ا. ماهو دور هيئة التمريض فى تحسين السلوك البيئى لأمهات الأطفال المصابين بالسرطان؟

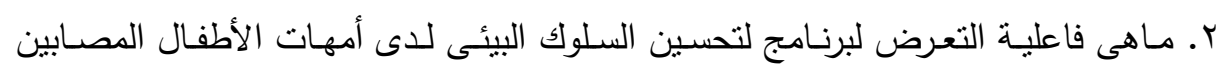

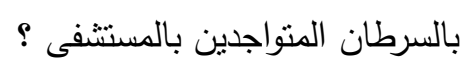

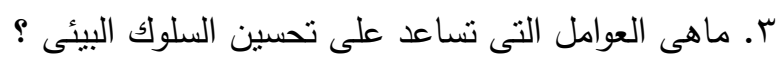

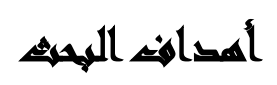

الهوف الرئيسى :

دعم السلوك البيئسى الإيجابى من أجل الحفـاظ على البيئة فى مستشفى سرطان الأطفال

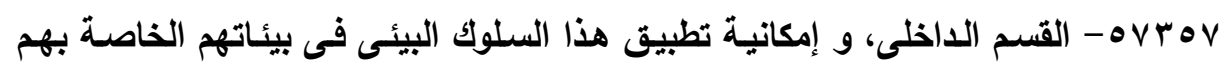
بوجه عام . مدام أهداف فرعية : أهو عام • التعرف على دور التمريض فى المستشفيات فى الحفاظ على البيئة .

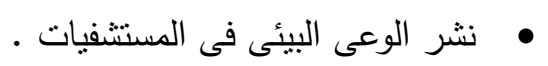

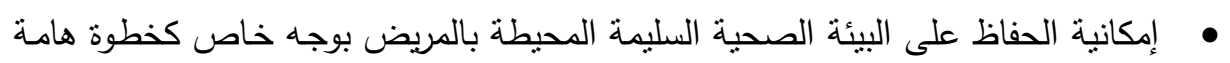
فى العلاج. • • الإهتمام بالبعد البيئى خطوة فى علاج مرضى السرطان.

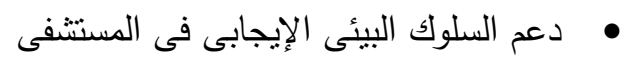

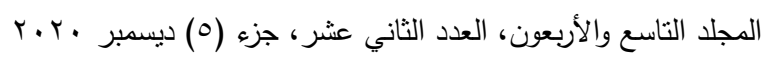
الترقيم الدولي 0826- ISSN 1110 


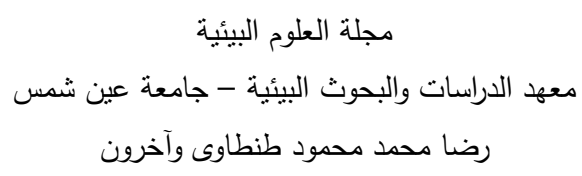

\section{أهميد التواسم}

أولاً : الأهمية النظرية:

• دعم وتتمية السلوكيات البيئية الإيجابية فى القطاع الطبى والمنشآت الصحية بهدف الحفاظ

على البيئة والصحة العامة للمرضى وذويهر •

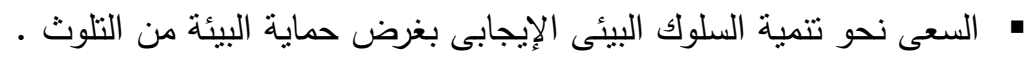
• التعرف على دور التمريض فى تتمية سلوك إيجابى معين نحو الحفاظ على البيئة.

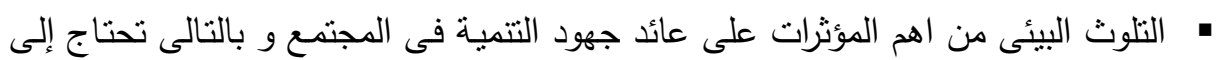

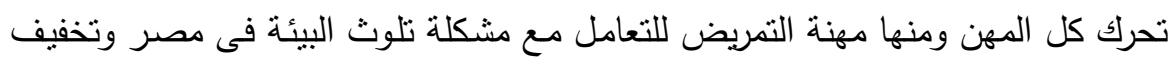
آنارها ونشر التوعية البيئية بين اهالى المرضى مما يجعل للمهنة مكانة منميزة بين المهن

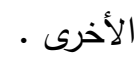
• استمرار التوعية ونشر التقافة البيئية يؤدى إلى تعديل السلوك السلبى تجاه البيئة وتتمية

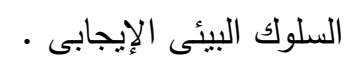
- إضافة جديدة فى مجال البحث العلمى. ثانياً: الأهمية التطبيقية : • نشر السلوك البيئى الإيجابى فى مستشفيات السرطان والمنشآت الصحية . • تفعيل البعد البيئى لدور الممرضة فى الحفاظ على البيئة ونشر السلوكيات البيئية الإيجابية

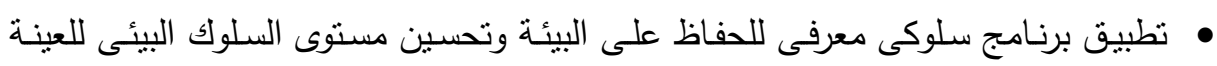
التجريبية، ومواجهة السلوكيات البيئية السلبية . • التحقق التجريبى من مدى فعالية برنامج سلوكى لتحسين السلوك البيئى للعينة التجريبية.

$$
\begin{aligned}
& \text { r.r. المجلد الناسع والأربعون، العدد الثاني عثر، جزء (0) ديسمبر } \\
& \text { الترقيم الدولي 0826- ISSN 1110 جنان }
\end{aligned}
$$




\section{تراسايت ساويمان}

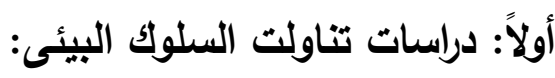

- فى بحث نم تقديمه من الباحث( فاضل خليل إبراهيم) فى جامعة الموصل عن اسباب

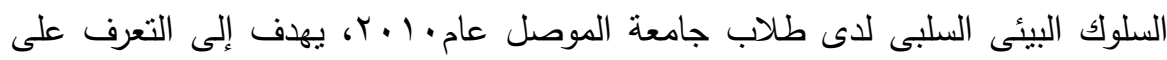
أسباب السلوك البيئى لدى طلاب جامعة الموصلو توصل إلى أن هنالك خمس اسباب للسلوك البيئى السلبى وهى: • المجتمع المحلى لا يعطى أهمية للعناية بالبيئة

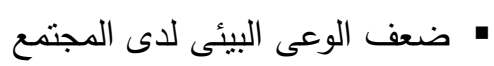

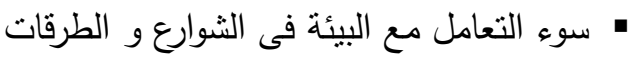

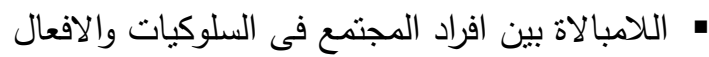

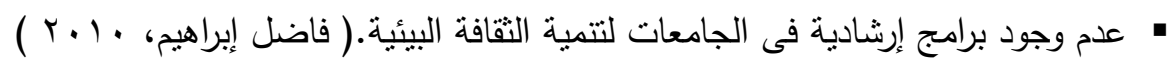

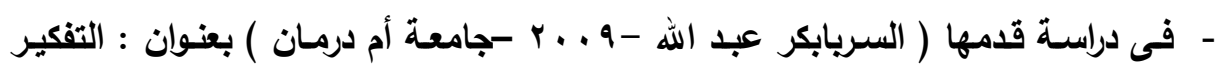

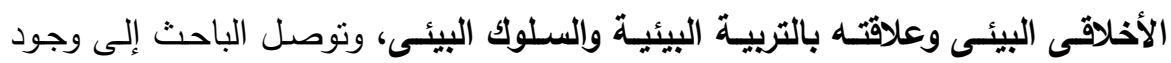

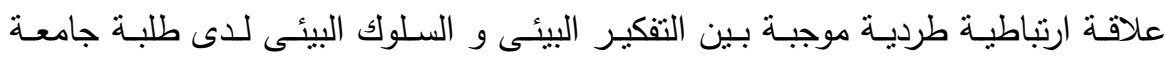

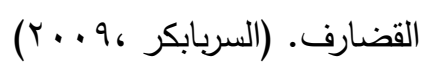

- وفى بحث مقدم من محمد إبراهيم عبد الحميد V. . . - . جامعة عين شمس، قام فيه بدراسـة فعاليـة برنـامج لتتميـة السلوك البيئى المنزلى لدى الأطفال المتخلفين عقليـا، وقد هيد

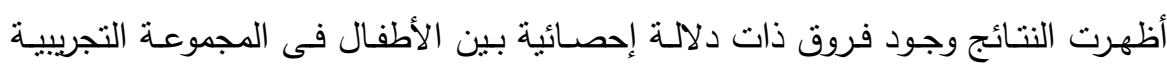

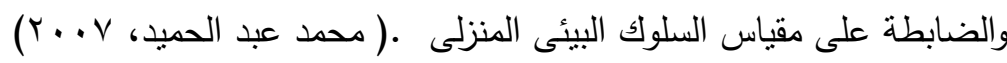

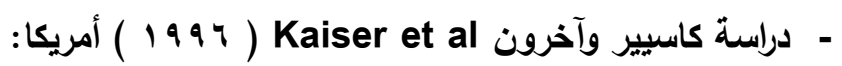

Ecological Behavior, Environmental Attitude, and Feelings of Responsibility for the Environment.

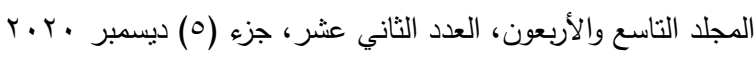

$$
\begin{aligned}
& \text { الترقيم الدولي 0826-1110 }
\end{aligned}
$$


السلوك البيئي والاتجاهات البيئية والشعور بالمسؤولية البيئية."

هدفت الدراسة إلى الكثف عن دور الموقف البيئي الذي يتخذه الفرد في التنبؤ عن بانئه السلوك البيئي الذي يمارسه من خلال مقياس السلوك البيئي من إعداد الباحثين، وأكدت نتائج الدراسات بوجود ثلاثة عوامل ذات أبعاد مستقلة إحصائيا ولكنها مترابطة في التأثير في إعائي السلوك البيئي للأفراد ذوي المعرفة البيئية وهى السلوك البيئي،والقيم البيئية، وأن المعرفة البيئية

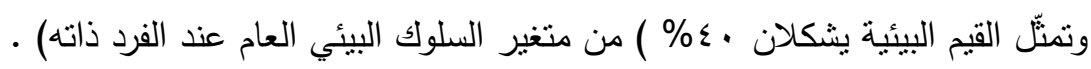

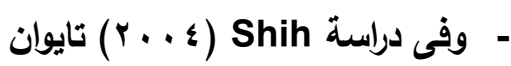

The Effects of an Environmental Education Program on Responsible Environmental Behavior and Associated Environmental Literacy Variables in Taiwanese College Students. "أثر برنامج في التربية البيئية على السلوك البيئي وعلاقته بالمتغيرات البيئية لدى طلاب كلية تايوان، وهدفت الدراسة إلى التعرف على أثز برنامج في التربية البيئية على السلوك البيئي .

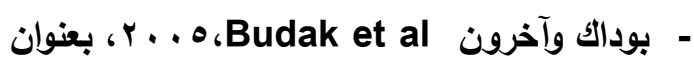
Behavior and Attitudes of Students Towards Environmental Issues at Faculty of Agriculture, Turkey. - السلوك والاتجاهات البيئية نحو القضايا البيئية لدى طلبة كلية الزراعة وتهدف إلى تقييم

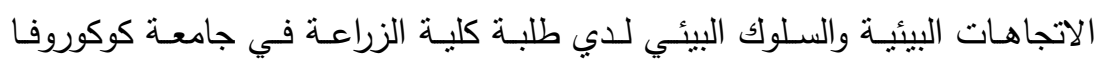

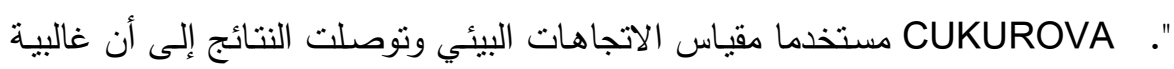
الطلبة • ^ \% يستخدمون وسائل الإعلام مصدراً للمعلومات حول القضايا البيئية دراسات متعلقة بالتلوث البيئى وعلاقت بالسلوك البيئى

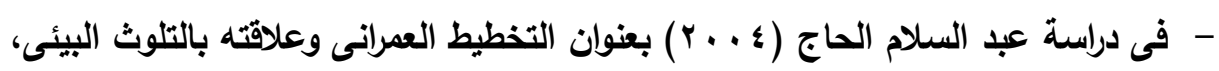

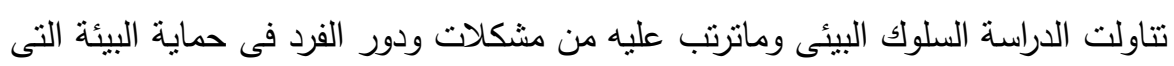

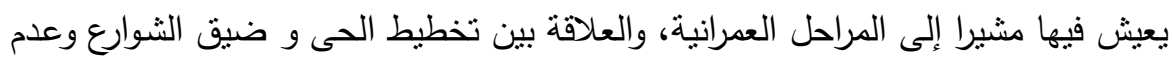

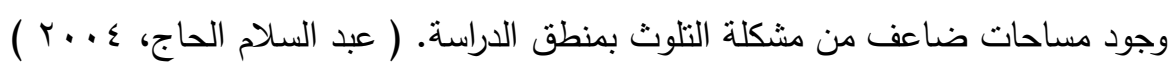

$$
\begin{aligned}
& \text { r.r. المجلد التاسع والأربعون، العدد الثاني عشر، جزء (0) ديسمبر }
\end{aligned}
$$

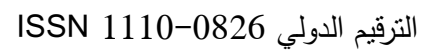




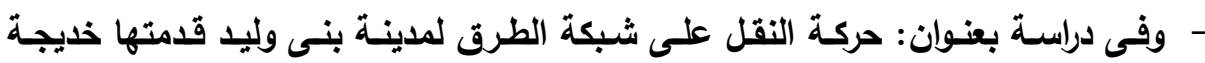

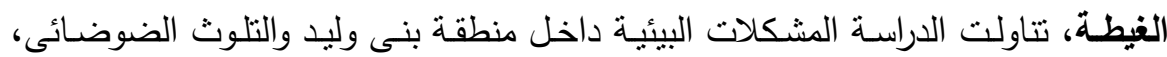
وأنواع النلوث الهوائى، وأن حركة المرور والإزدحام من مسببات التلوث البيئى .( خديجة

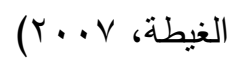

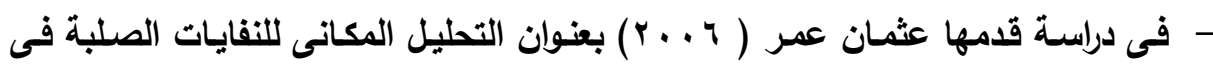
منطقة بنى وليد، منتاولا فيه مشكلة النفايات الصلبة وانواعها وتوزيعها المكانى وانتشارها فى المناطق السكنية وما تسببه من تلوث وإنتشار الحشرات والقوارض التى تلحق الضرر

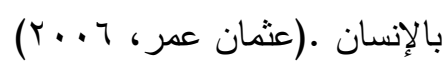
دراسات متعلقة بدور التمريض: بالإنسان • -ركزت بعض الدراسـات على اهميـة تدريب العـاملين فى المجالات الطبيـة على مهارات الإتصـال وخصوصسا التمريض نظرا لكثرة الإحتكاك بين التمريض والمرضى وذويهم وهذ

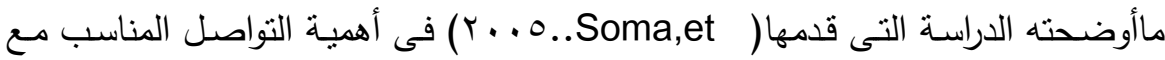

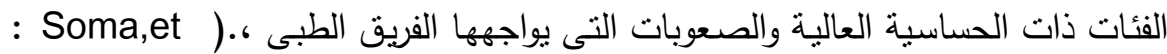
( r...o. - تتاولت دراسة عن (التكامل بين معايير الجودة الثشاملة ورفع كفاءة الأداء للعاملين فى مجال

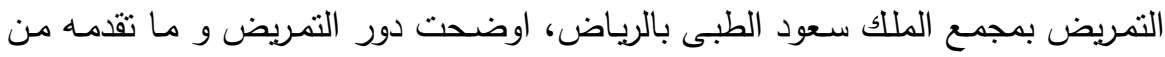
رعاية طبية وتثقيف صحى وطالبت بتفعيل الجانب التوعوى للتمريض ـ ( نجوى عبد الله،

\section{التعقيب على الاراسات السابقة:} - اتفقت دراسة كل من ( السربابكر عبد اله -9 . . . - - جامعة أم درمان ) ،محمد إبراهيم عبد

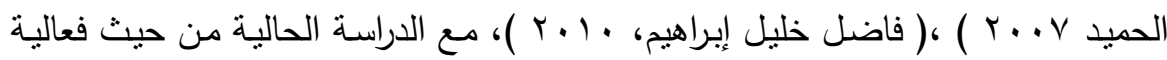

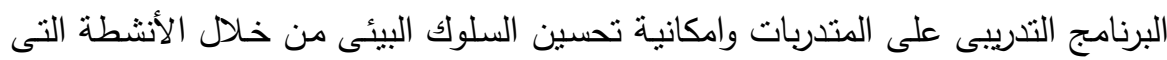

$$
\begin{aligned}
& \text { r.r. المجلد التاسع والأربعون، العدد الثاني عشر ، جزء (0) ديسمبر } \\
& \text { الترقيم الدولي 0826-1110 1SSN }
\end{aligned}
$$


تعرضـن لها ولكن أختلفت من حيث طبيعـة العينـة، ونوعيـة البرنـامج وطبيعة الأنشطة المقدمة .

- امـا دراسـة 2005. وضحت دور التمريض فى تتمية السلوكيات الإيجابية

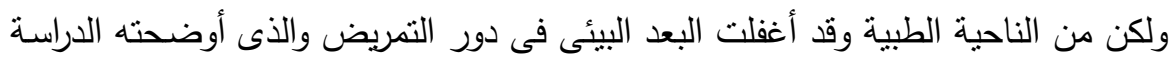

$$
\text { الحالية. }
$$

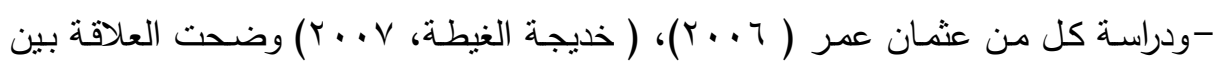
التلوث البيئى والسلوكيات البيئية السلبية.

\section{الإلطار اللنظلريه}

$$
\begin{aligned}
& \text { برنكز الإطار النظرى على المحاور الآتية: }
\end{aligned}
$$

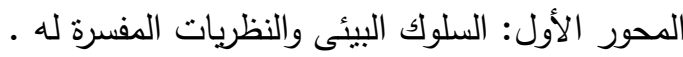

$$
\begin{aligned}
& \text { المحور الثانى: تعديل السلوك البيئى و التظريات المفسرة . } \\
& \text { المحور الثالث: التلوث البيئى وعلاقته بالسلوك البيئى . } \\
& \text { المحور الرابع: التمريض ودوره المجتمى و النظريات المفسرة . }
\end{aligned}
$$

\section{أولاً: مفهوم السلوك Behavior}

السلوك لغةً يعرف على أنه: اى تصرف و يقصد به الإستجابة الكلية التى يبديها الكائن الحى

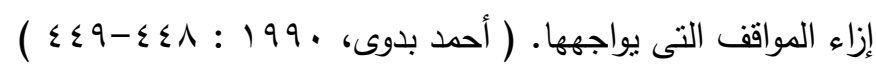

السلوك أيضا: مجموعة من الحركات المنسقة التى تقود إلى وظيفة ما، فتمكن صاحبها إلى الى

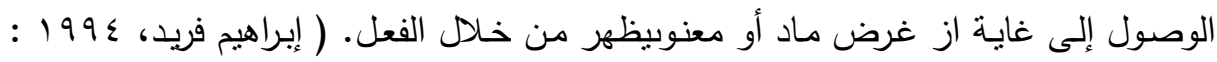

السلوك هو : كل مايصدر عن الفرد من نشاط شخصى يرتبط بطبيعة الإنسان نتيجة لإتصاله

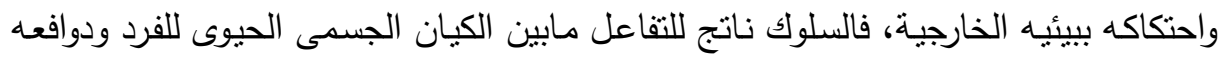

$$
\begin{aligned}
& \text { r.r. المجلد التاسع والأربعون، العدد الثاني عشر، جزء (0) ديسمبر } \\
& \text { التزقيم الدولي }
\end{aligned}
$$




\section{مجلة العلوم البيئية \\ معهد الدراسات والبحوث البيئية - جامعة عين شمس لئه رضا محمد محمود طنطاوى وآخرون}

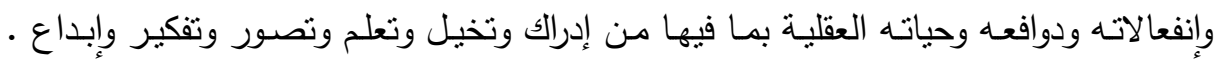

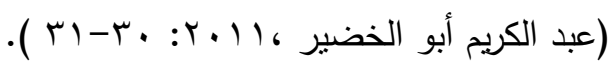

ثانياً::السلوك البيائى: : Environmental Behavior ويعرف السلوك البيئى على أنه الجزء من تفاعل الكائن الحى مع بيئته، والذى مكن من خلاله ان تجرى حركة هذا الكائن فى المكان والزمان، والذى ينتج عنه تغيير غى جانب واحد على لى

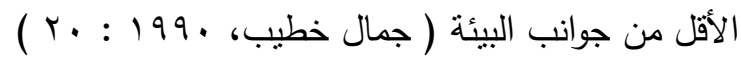
السلوك البيئى أنه كل فعل او تصرف صحيح يقوم بـه الإنسان ويئُر إيجابياً على عناصر

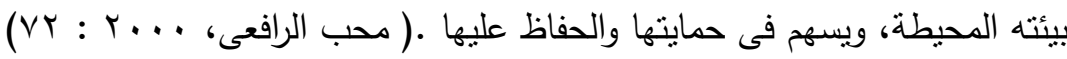

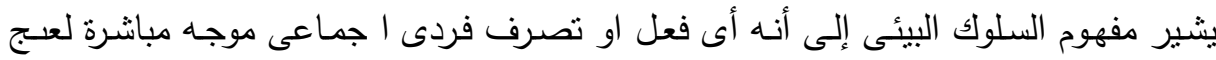
اوحل القضايا و المشكلات البيئية .(حسن شحاتة، زينب النجار ، ؟ . . ب) ثالثاً : مفهوم البيئة: وتعرف البيئة على أنها الأرض وما تضمنه من مكونات غير حية ممنلة فى مظاهر سطح الأرض من الجبال والسهول و المجارى المائية، ومكونات حية ممنلة فى النباتات والحيوانات البرية و المائية، و مايحيط بالأرض من غلاف غارئ يضم العناصر الأساسية لوجود الحياة

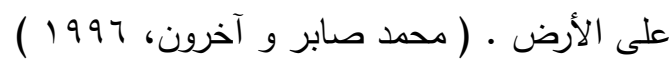
تعريف أخر عن البيئة هى : الإطار الذى يمارس فيه الإنسان حياته بما فى ذلك ظروف، وإن و

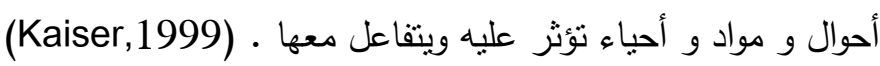

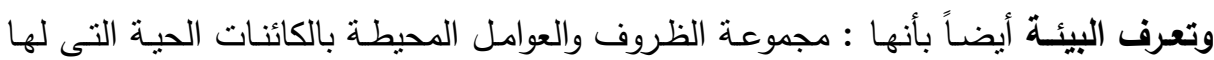

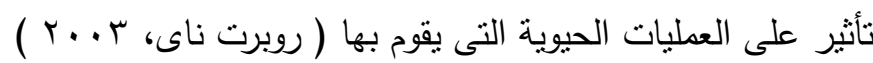

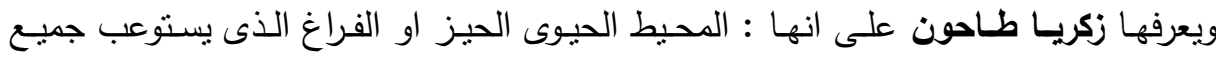
الكائنات وأنها الحالة التى تحقق الصحة والسلامة والأمان و اراحة الذهنية والعصبية والنفسية النها

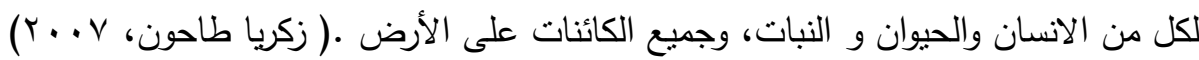

$$
\begin{aligned}
& \text { r.r. المجلد التاسع والأربعون، العدد الثاني عشر، جزء (0) ديسمبر } \\
& \text { الترقيم الدولي 0826-1110 1SSN }
\end{aligned}
$$


والمقصود بالبيئة فى الدراسة الحالية : بيئة المستشفى الذى يتلقى فيها الطفل العلاج ،وبيئة

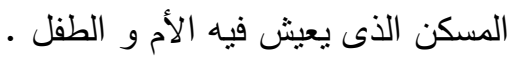
رابعاً: تعريف التلوث البيئى:

وعرفه العزة • •91 1، انه التغير الحاصل فى الخواص الكيميائية والفيزيائية و البيولوجية

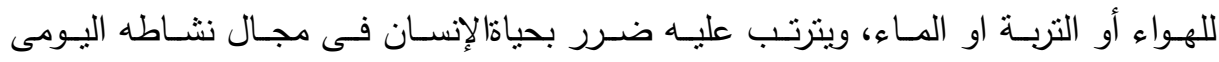
والصناعى والزراعى مسبباً الضرر والتلف لمصادر البيئة الطبيعية ( شحاتة العزة ، ـ191 ( ) وقد ظهرت مشكلة التلوث البيئى مـع مجىء عصر الصناعة والتكنولوجيا وقد أهتمت بها لئه الدراسات و الأبحاث لما اثتملت عليه من أثار ضارة بالبشرية والممتلكات و الموارد الطبيعية

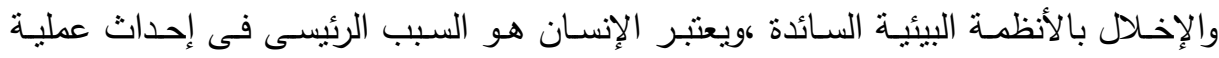

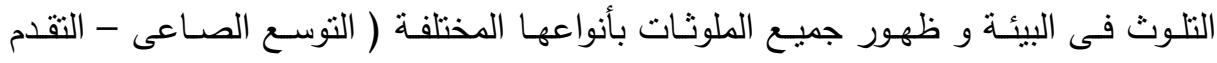
التكنولوجى - سوء إستخدام الموارد - الإنفجار السكانى )( رشيد حمد، محمد سعيد : .99 (1)

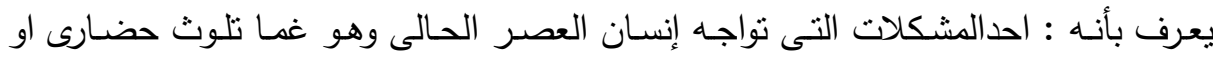

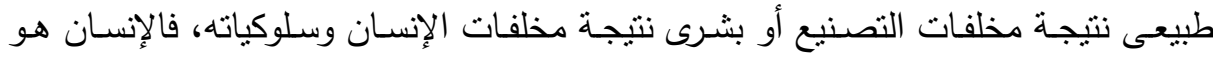

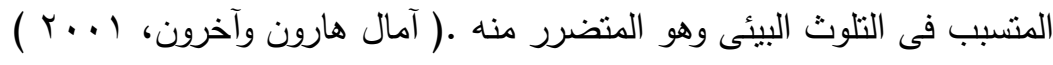
خامساً : تعريف مرض السرطان:

يعتبر مرض السرطان من الأمراض العصرية المستعصية التى يصعب الثفاء منها و

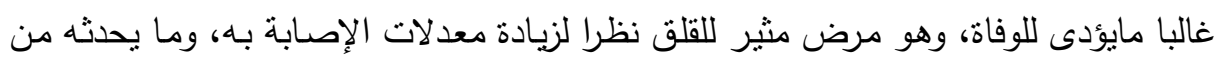

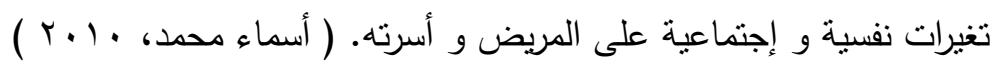

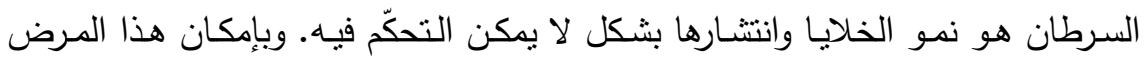

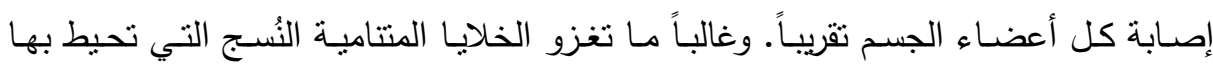
ويمكنها أن تتسبّب في نقائل نظهر في مواضع أخرى بعيدة عن الموضـع المصاب. ويمكن

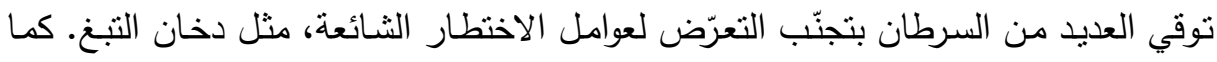

$$
\begin{aligned}
& \text { r.r. المجلد التاسع والأربعون، العدد الثاني عثر، جزء (0) ديسمبر } \\
& \text { الترقيم الدولي 0826-1110 }
\end{aligned}
$$


يمكن علاج نسبة كبيرة من السرطانات عن طريق الجراحة أو المعالجة الإشعاعية أو المعالجة

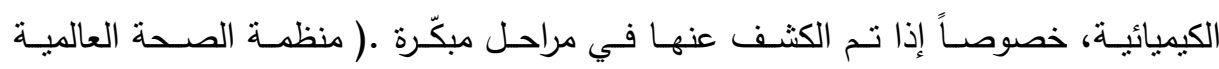
$(r \cdot r \cdot:$

\section{سادسا: تعريف البرنامجج:}

البرنامج هو : التكتيك او الطريقة أو الأسلوب او النظام او الخطة العلمية التى يصنعها الفرد

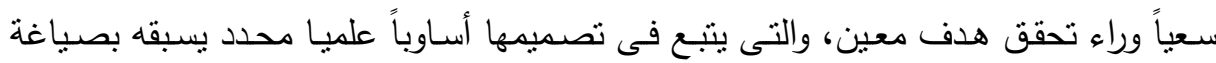

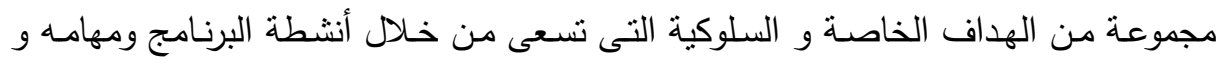

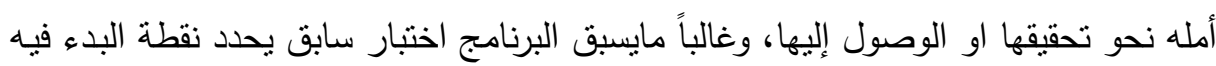

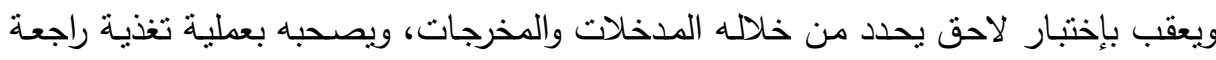

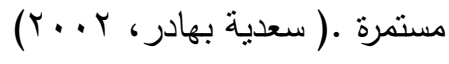

هو مجموعة من الانشطة أو بيان كلى عن المواقف وتحديد المشكلات النفسية والأهداف بهاف

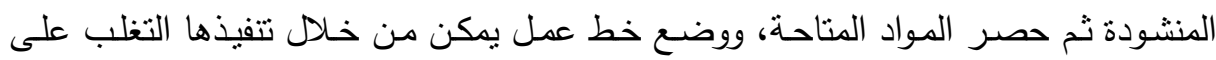
المشكلات وتحقيق الأهداف فى أقصر وقت مدكن و بأقل مجهود ( جودت عبد الهادى وسعيد

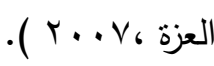

\section{التعاريف الإجرائية}

التعريف الإجرائى للمعارف البيئية: هو جميع الدفاهيم والتعريفات عن البيئة بأنواعها (الطبيعية

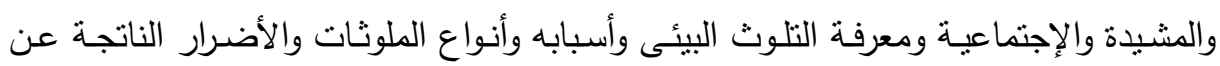
النلوث البيئى. التعريـف الإجرائسى للبيئـة الإجتماعيـة: مجموعـة المعارف والمعلومـات والاتجاهـات والميول والدوافع والمعتقدات داخل الفرد تجاه البيئة المحيطة والتى تؤثر على سلوك وتصرفات الفرد إما

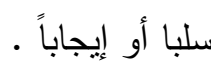

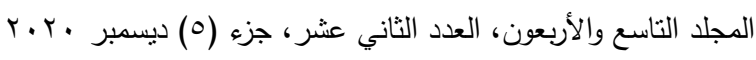

$$
\begin{aligned}
& \text { الترقيم الدولي 0826-1110 }
\end{aligned}
$$


المحور الأول : السـلوك البيئسى :نظريـة لإنتثـار الإجتمـاعى : والتـى وترى أن الفرد يتأثر

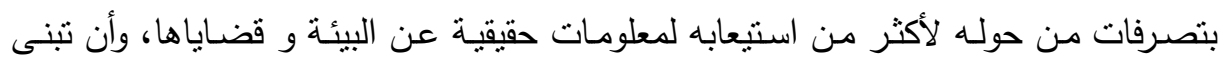
السلوك البيئى بنمطيه الإيجابى والسلبى يتحقق من خلال إنتثاره بيئياً،وأن المحاكاة أكثر تأثنير من أى برامج تستهدف إكساب السلوك البئيى الإيجابى . Gelntis :2004,pp3-4)

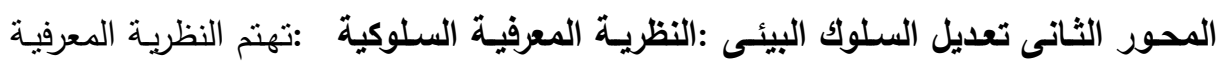
بالإدراك و المعرفة ويرى Gold Stein أن الإدراك أهم سمات النظرة المعرفية وهو عملية أساسية لأنه يربط الإتجاهات والأفكار والمشاعر بالحياة الإجنماعية والبيئية التى نعيش فيها.

( Malcolm, payne,1991,PP 184-186)

المحور الثالث : التلوث البيئى وعلاقته بالسلوك البيئى: نرى أن الإنسان هو السبب الرئيسى

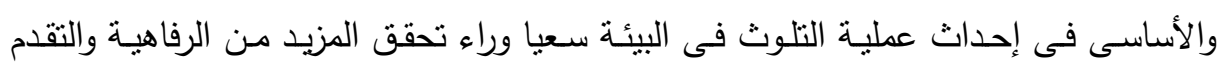

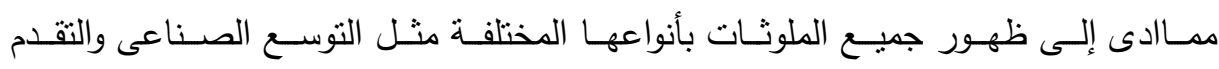

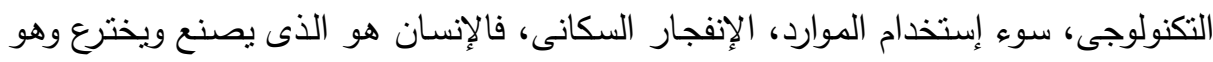

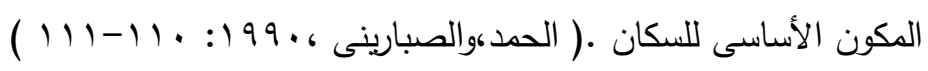
المحور الرابـع : التمريض و دره المجتمعى :نظريـة الدور الإجتمـاعى: تعد من النظريات

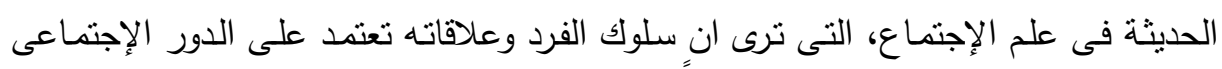

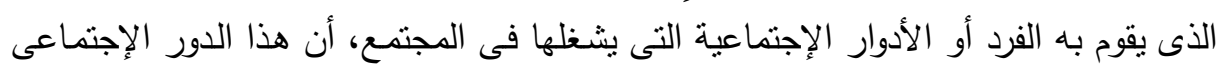

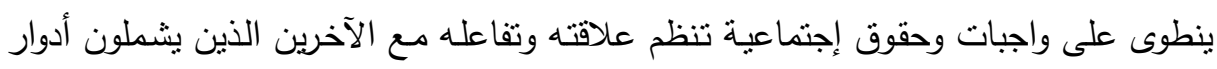

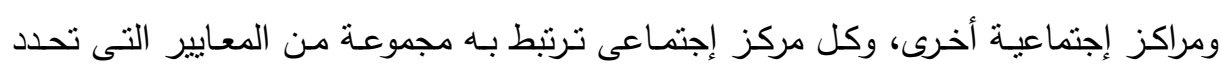

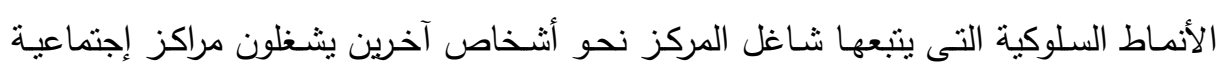
(Deutch,Robert,(1995):173-176). أخرى الأن 


$$
\text { مجلة العلوم البيئية }
$$

معهد الدراسات والبحوث البيئة - جامعة عين شمس اليئة رضا محمد محمود طنطاوى وآخرون

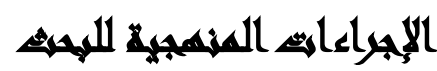

اتفق الباحثون على أن لكل دراسـة ثناث مجالات رئيسي يجب على الباحث توصيفها عند تخطيط إجراء البحث و يعد تحديد مجالات الدراسـة بطريقة موضوعية من الاجراءات المنهجية، وفى هذا الجزء سيتم إستعراض المجالات على النحو التالى:

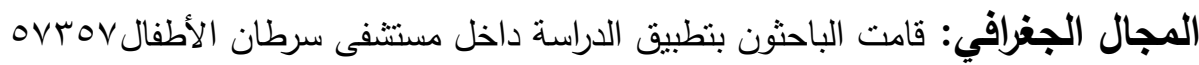
المجال البشري: قامت الباحثون بإجراء الدراسة على عينة من أمهات الأطفال المصابين

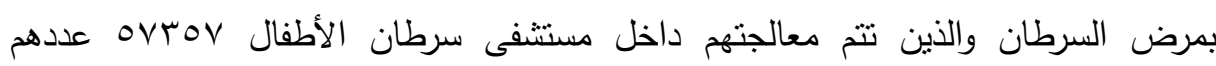

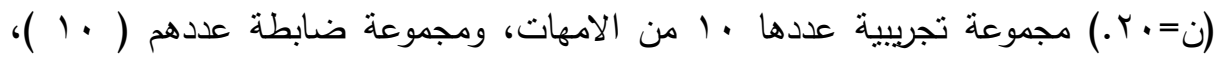

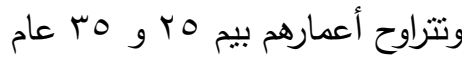
المجال المكانى: مستشفى سرطان الاطفال العيادات الخارجية والقسم الداخلى للأطفال المقيمين بالمستشفى . المان

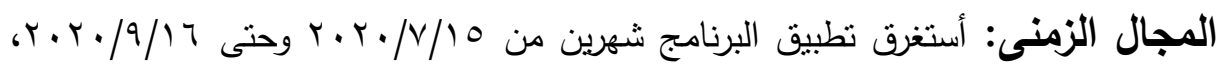

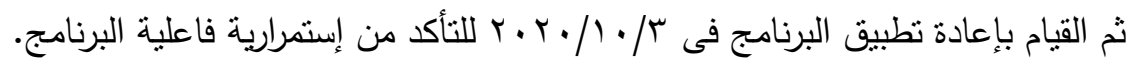

\section{أسواهي المهنه}

( ) عينة الدراسة: تم إختيار عينة الدراسة فى إطار محدات معينة وهى أن يتراوح أعمارهن بين هب و هب عام ومن مقيمين المستتفى مع أطفالهن المصابين بالسرطان فترة

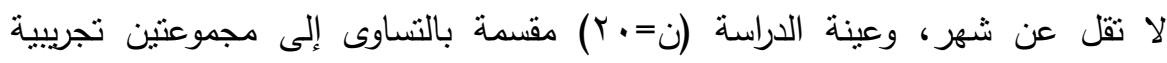
وضابطة ونم حساب التجانس بين المجموعتين الضابطة والتجريبية على عدة متغيرات وهى:

* الأكاء: تم حساب التجانس بين المجموعتين الضابطة و التجريبية على متغير الذكاء بقيمة

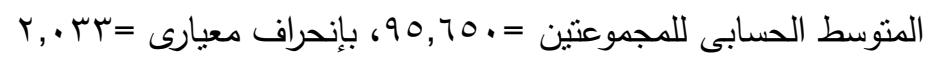

$$
\begin{aligned}
& \text { r.r. . المجلد التاسع والأربعون، العدد الثاني عثر ، جزء (0) ديسمبر } \\
& \text { الترقيم الدولي 0826-1110 }
\end{aligned}
$$




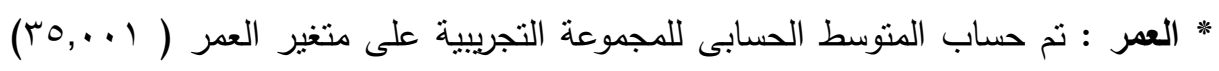

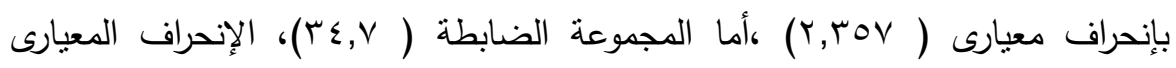

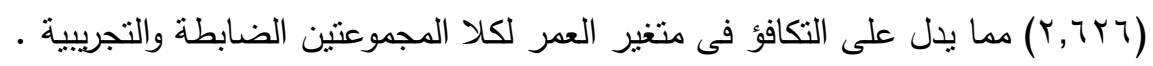

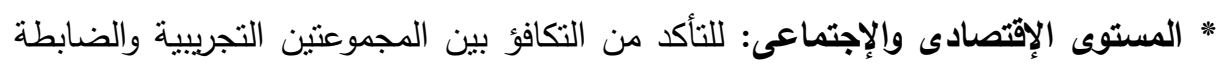

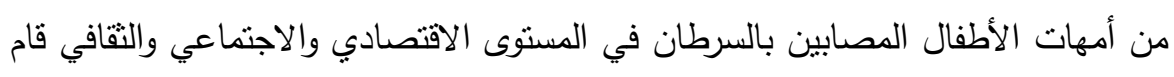
الباحثون بحساب اختبار مان ويتتي اللابارامتري لدلالة الفروق بين المجموعات المستقلة الإنة

جدول (1)

\begin{tabular}{|c|c|c|c|c|c|c|c|}
\hline \multirow[b]{2}{*}{ الدلالة } & \multirow[b]{2}{*}{ قيمة } & \multirow[b]{2}{*}{ قيمة } & \multicolumn{2}{|c|}{ ضابطة (ن= ، 1 ) } & \multicolumn{2}{|c|}{ تجريبية (ن= + 1 (1) } & \multirow{2}{*}{ المجموعة الميم } \\
\hline & & & رتبموع & رتب & رتبّوع & رتب & \\
\hline غير دالة & ., r & $\sum \uparrow, 0$ & $1 \cdot 1,0$ & $1 \cdot, 10$ & $1,1,0$ & 1,10 & الاقتصادي \\
\hline غير دالة & .,YY. & $\varepsilon, 0$ & 90,0 & 9,00 & $11 \varepsilon, 0$ & $11, \leqslant 0$ & الاجتماعي \\
\hline غير دالة & . & $\varepsilon r$ & $11 \pi$ & $11, \pi$. & $9 \mathrm{~V}$ & $9, \vee$. & الثقافي \\
\hline غير دالة &., 119 & $\varepsilon \vee, 0$ & $1 . v, 0$ & $1,, v_{0}$ & $1 . Y, 0$ & $1, r_{0}$ & الدرجة الكلية \\
\hline
\end{tabular}

وأنثارت النتائج إلى عدم وجود فروق دالة إخصائيا بين الأمهات فى المجموعتين التجريبية والضابطة على المستوى الإقتصادى والإجنماعى والثقافى.

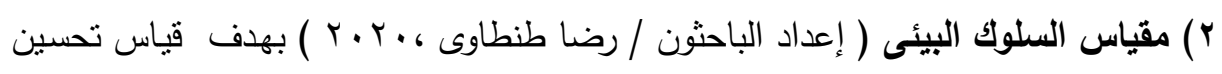

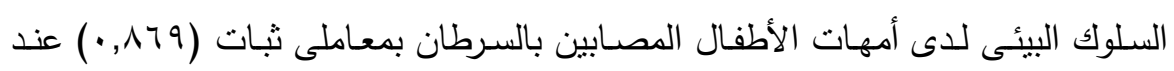

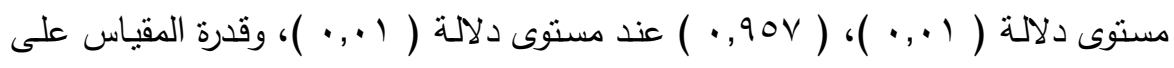

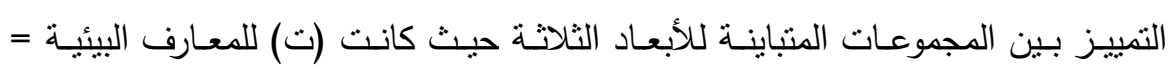

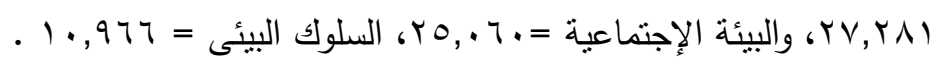

الكفاءة السيكوميترية للمقياس: للتأكد من الكفاءة السيكوميترية للمقياس قام الباحثون بتطبيق

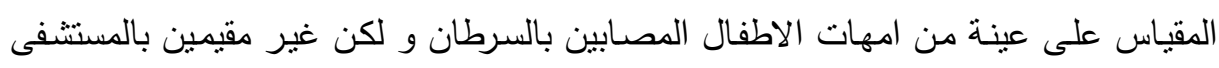

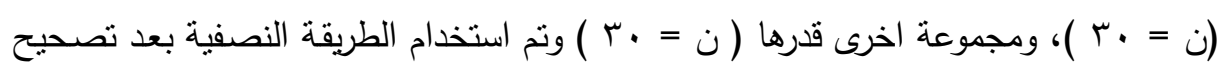

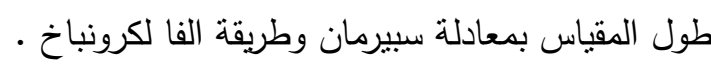

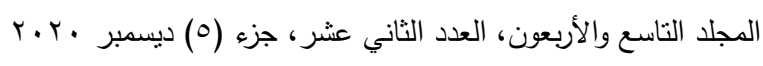


مجلة العلوم البيئية

معهد الدراسات والبحوث البيئية - جامعة عين شمس لئه رضا محمد محمود طنطاوى وآخرون

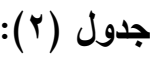

\begin{tabular}{|c|c|c|c|}
\hline مستوى الدلالة & معامل الثبات & طرق حساب الثبات & 5 \\
\hline$\cdot, \cdot 1$ & •, 179 & التجزئة النصفية بعد تصحيح طول المقياس & 1 \\
\hline., .1 & $\cdot, 90 \mathrm{~V}$ & معامل ألفا لكرونباخ & $r$ \\
\hline
\end{tabular}

وأنشارت النتائج إلى أن معاملي الثبات وبرغم اختلاف طريقتي حسابهما إلا أنهما دالين ومرتفعين. مما يشير إلى تمتع المقياس بثبات مقبول. حساب الصدق للمقياس

تم حساب صدق التميز بين المجموعات المتباينة للمقياس كما هو موضح بالجدول (r)

\begin{tabular}{|c|c|c|c|c|c|c|}
\hline \multirow{2}{*}{ مستوى الدلادة } & \multirow{2}{*}{ قيمة "ت" } & \multicolumn{2}{|c|}{ أمهات غير المرضى } & \multicolumn{2}{|c|}{ أمهات الأطفال المرضى } & \\
\hline & & انحراف & متوسط & انحراف & متوسط & \\
\hline$\cdot, \cdot 1$ & $r V, Y \wedge)$ & $1, \wedge T \varepsilon$ & $r \varepsilon, \wedge \ldots$ & $1, r \leqslant 0$ & זrד, & المعارف البيئية \\
\hline$\cdot, \cdot 1$ & ro, r. & $r, r \leq q$ & $r_{0}, 1 \ldots$ & $\cdot, \wedge \wedge 9$ & T & البيئة الاجتماعية \\
\hline$\cdot, \cdot 1$ & $1 ., 977$ & $r, Y \wedge O$ & $r \leqslant, 974$ & $r, A \Lambda r$ & $10, \varepsilon \ldots$ & السلوك البيئي \\
\hline$\cdot, \cdot 1$ & ro,rד4 & 0, rTO & $V \varepsilon, \wedge T 4$ & $\varepsilon, \Gamma r Y$ & $\varepsilon r, \cdot T\}$ & الدرجة الكلية \\
\hline
\end{tabular}

وأنثارت النتائج إلى وجود فروق دالة إحصائيا بين منوسطات درجات عينتي أمهات الأطفال المصابين بالسرطان وأمهات الأطفال غير المرضى على دلى مقياس السلوكيات البيئية

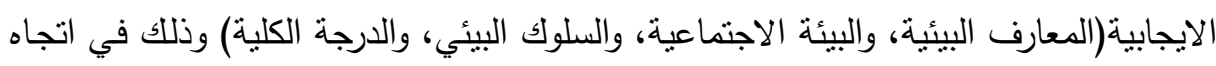

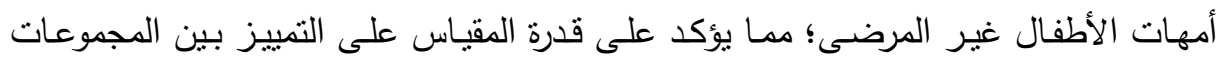
المتباينة.

$$
\begin{aligned}
& \text { r.r. المجلد التاسع والأربعون، العدد الثاني عثر ، جزء (0) ديسمبر } \\
& \text { الترقيم الدولي 0826-1110 الأنوني }
\end{aligned}
$$


r) برنـامـج تحسين السلوك البيئسى ( إعداد الباحثون ) ت يحتوى على معلومات و معارف عن البيئة و النلوث البيئة فى شكل صور و مقاطع فيديو و معلومات مكتوبة ينم قرائتها

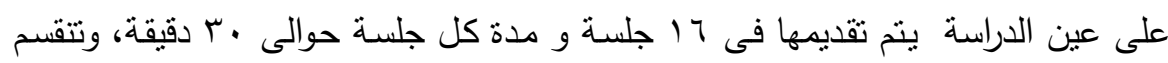
إلى :

• الجلسـة التمهيديـة و تقوم فيـه الباحثة بـالجلوس مـع هيئة التمـريض لتوضيح محتويـات

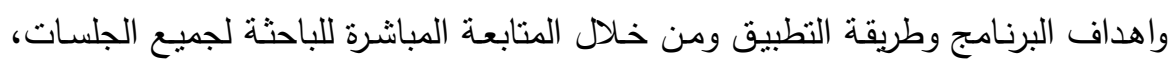
وتقوم مسئولة التدريب بتوضيح هذه الأهداف للأمهات عينة الدراسة ولنة

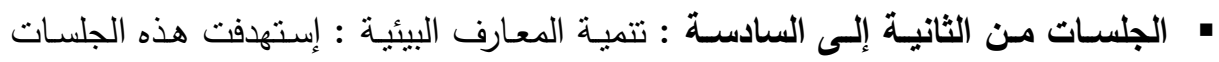
تعريف الأمهات بكيفية الحصول على المعلومات اللازمة عن تلوث البيئة،وأسبابه، وأنواع الملوثات، والأمراض الناتجة عن التلوث البيئى والمضرة بصحة الإنسان ثم يتم الربط بين التلوث البيئى والأمراض التى تصيب الإنسان والحيوان والنبات، وينت عرض صور لألن الأنوع

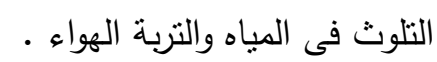

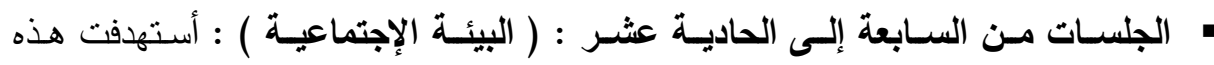

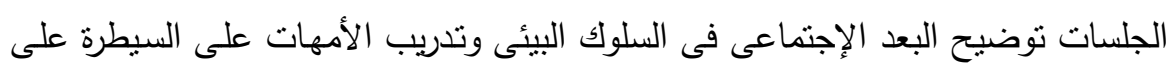

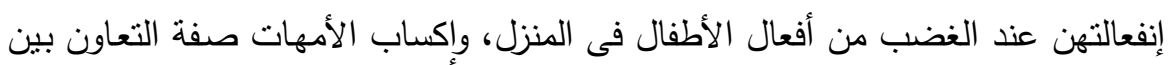
أفراد الأسرة للحفاظ على البيئة. - الجلسات من الثانية عشر وحتى السادسة عشر : ( تنميـة السلوك البيئسى الإيجابى )

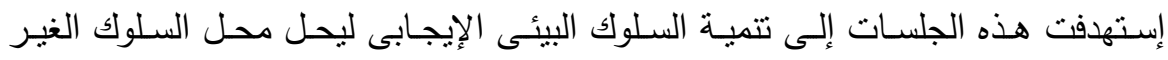

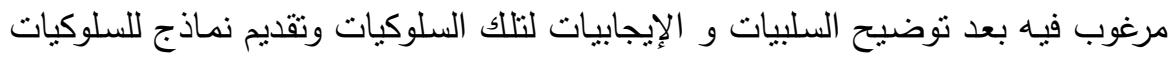
الإيجابية التى تحافظ على صحة الفرد مثل إختيار نوع البلاستيك الجيد والصحى، وتهوية المسكن وغسل الخضروات وغيرها من السلوكيات البيئية الإيجابية .

$$
\begin{aligned}
& \text { المجلد التاسع والأربعون، العدد الثاني عشر، جزء (0) ديسمبر ·.r.r. }
\end{aligned}
$$

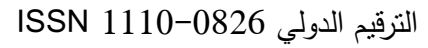


ل تحسين وتتميـة السلوك البيئى لدى امهات الأطفال المصابين بالسرطان من خـلال عدة انشطة يتم التدريب عليها وبعض المعلومـات التى يتم اكسابهن للمحافظـة على البيئة المحيطة والتى بدورها يكون لها دور مؤثر وفعال فى مرحلة علاج الطفل وأيضا للمحافظة

$$
\text { على البيئة لجميع أفراد الأسرة }
$$

ل إمكانية تعزيز ونشر السلوك الإيجابى وصيانة البيئة الدحيطة بالأمهات موضوع الدراسة

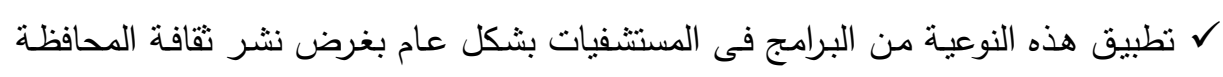

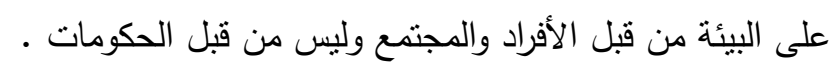

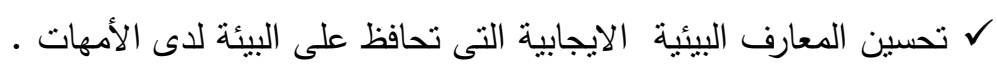

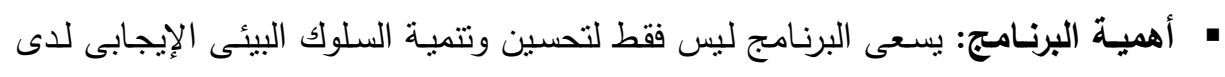

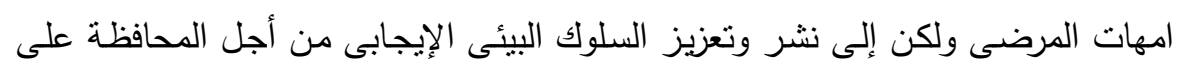
لإنسان الذى هو سيد البيئة. - المساهمة فى تحسين الصحة وسرعة الإمتنال للشفاء للمصابين بالإضافة إلى تفعيل دور

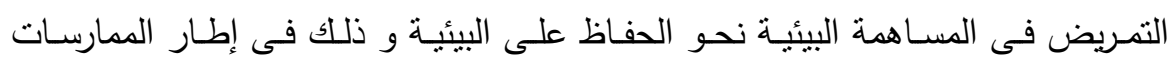
السلوكية الصحيحة مثل النظافة الثخصية ونظافة المكان المحيط. - الحد من التلوث البيئى لتوفير بيئة صحية سليمة التى هى من اساسيات جودة الحياة.

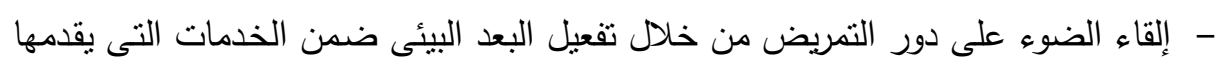
التمريض للمجتمع بجانب الخدمات الطبية.

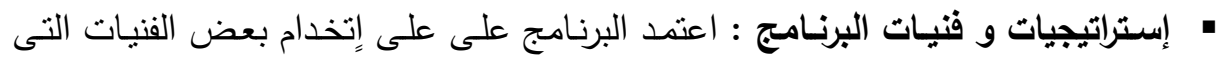

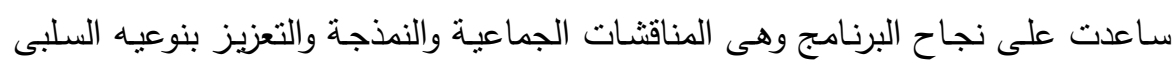

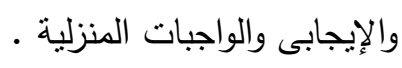
؛ ) اختبـار الـذكاء المصفوفات المتتابعـة ل رافـن : وتستخدم المصفوفات دون التقيد بزمن

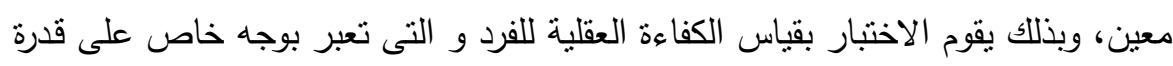

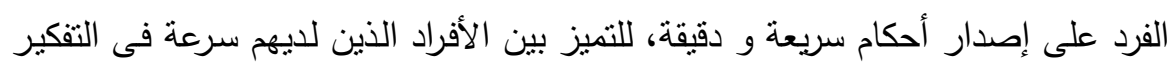
228

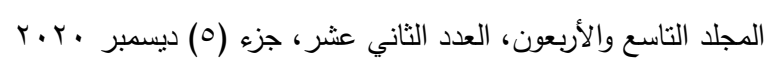
الترقيم الدولي 0826- ISSN 1110 
عن الذين لديهم بطء فى التفكير و ينم التصحيح طبقا لمفتاح التصحيح و بمعامل ثبات

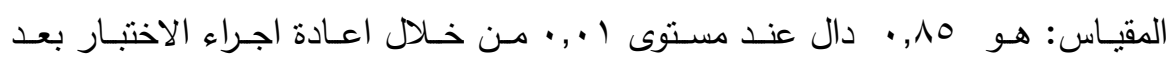

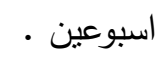

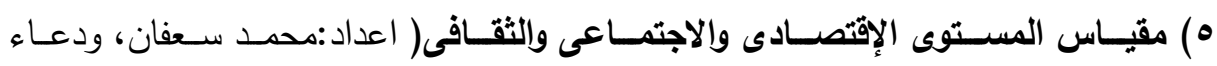

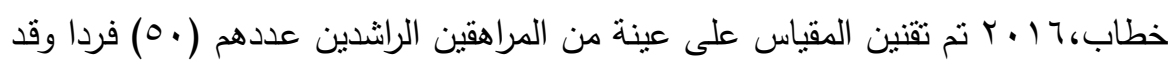

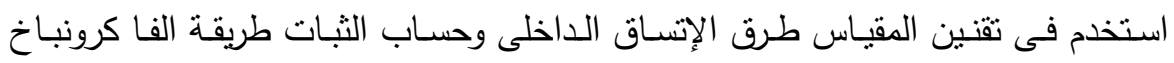

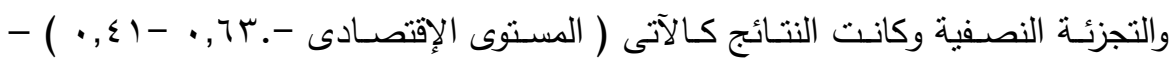

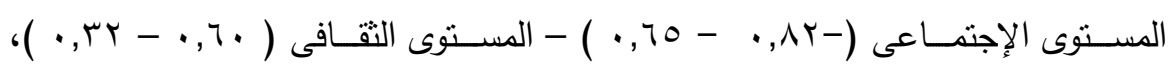

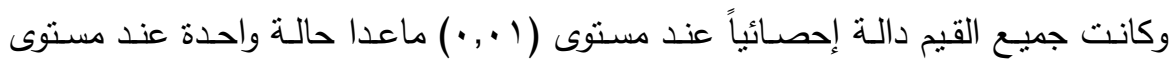
$\cdot(\cdot, \cdot 0)$

الأسـاليب الإحصـائية المسـتخدمة: تم تفريخ البيانـات عن طريق البرنامج الإحصـائى

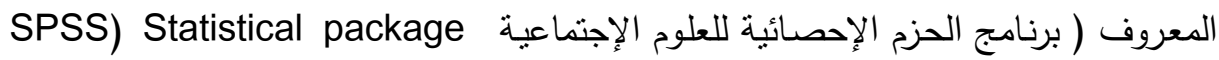
for social science SPSS) الإرتباط بين المتغيرات، وكذلك عرض المقارنات بين المجموعات التجريبية والضابطة للتأكد مـن صـحة الفـروض التى تقوم عليهـا الدراسـة، و قـد تمـت المعالجـة الإحصـائية بإسـتخدام

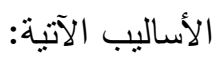
ا ـ اختبار ت البارامترى لدلالة الفروق بين المجموعات المستقلة .

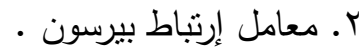
r. معادلة سبيرمان براون لتصحيح طول المقياس.

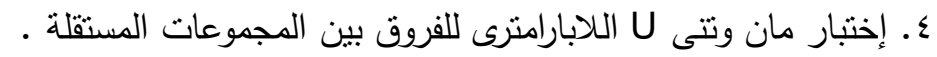
o. إختبار ولكوكسون W اللابارامترى للفروق بين المجموعات المرتبطة 
مجلة العلوم البيئية

معهد الدراسات والبحوث البيئية - جامعة عين شمس لئة

رضا محمد محمود طنطاوى وآخرون

\section{إجبراعايت تطبرية الميهث}

اتبعت الباحثون في الدراسة الخطوات التالية:

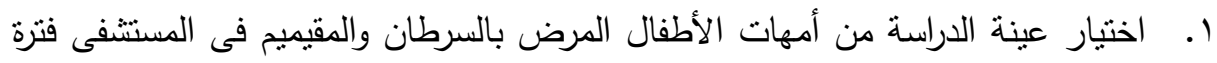

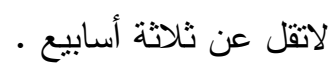

r. قامت الباحثون بحساب التجانس بين أفراد العينة من حيث العمر الزمني والمستوى لإنه الاقتصادي والاجتماعي والثقافي للأسرة، ودرجة الذكاء لاى الأمهات والقياس القبلي لدرجة لئل

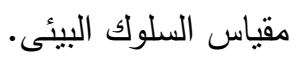

r. تطبيق مقياس السلوك البيئى علي أفراد العينة قبل تطبيق البرنامج. ع. ـقسيم أفراد العينة إلى مجموعنين: إحداهما تجريبية والأخرى ضابطة.

ه. تم نطبيق البرنامج المستخدم في الدراسة علي أفراد العينة التجريبية دون الضابطة وأستغرق تطبيق البرنامج شهر ونصف في الفترة من 0

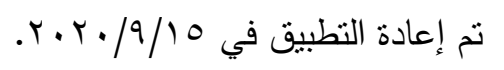

T. ـ وبعد الانتهاء من تطبيق البرنامج، قام الباحثون بتطبيق مقياس السلوك البيئى على الأمهات لأطفال مصابين بالسرطان ومقيمين بالمستشفى وهم أفراد المجموعة التجريبية والضابطة، ثم المقارنة بينهما في الدرجات قبل وبعد نطبيق البرنامج.

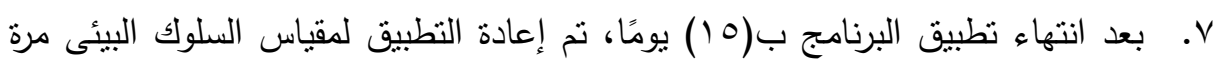
أخيرة وذلك علي أفراد المجموعة التجريبية لمعرفة مدى استمرارية فاعليته.

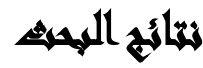

نتائج الفرض الأول: ينص على "توجد فروق دالة إحصائيا بين متوسطات رتب درجات

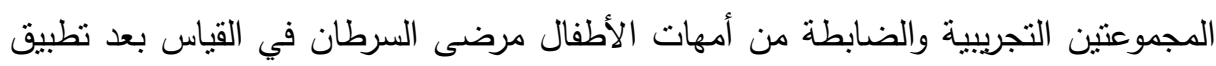

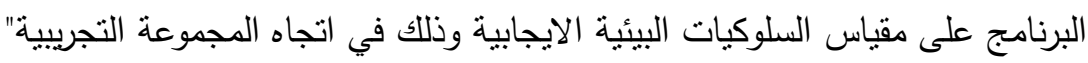

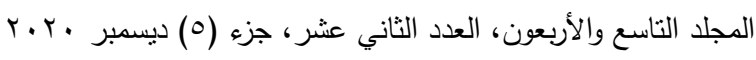

$$
\begin{aligned}
& \text { الترقيم الدولي 0826-1110 }
\end{aligned}
$$


وللتأكد من صدق هذا الفرض حسبت الباحثون اختبار (مان ويتتي) اللابارامتري لدلالة الفروق بين المجموعات المستقلة، ويوضح ذلك جدول ( ع ) ).

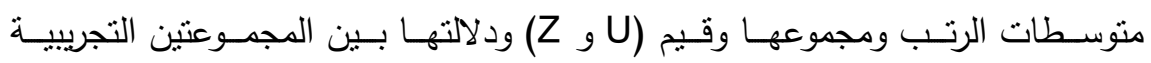
والضابطة في القياس بعد البرنامج على مقياس السلوكيات البيئية الايجابية .

\begin{tabular}{|c|c|c|c|c|c|c|c|}
\hline \multirow[b]{2}{*}{ مستوى } & \multirow[b]{2}{*}{ " قيمة "Z" } & \multirow[b]{2}{*}{ قيمة "U" } & \multicolumn{2}{|c|}{ ضابطة (ن=. 1) } & \multicolumn{2}{|c|}{ تجريبية(ن= + 1 } & \multirow{2}{*}{ المجموعة القيم } \\
\hline & & & مجموع رتب & متوسط & رجموع & متوسط & \\
\hline$\ldots \ldots 1$ & $r, \wedge) \leqslant$ & صفر & 00 & 0,0 & 100 & 10,0 & المعائية \\
\hline 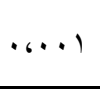 & $r, \wedge r q$ & صفر & 00 & 0,0 & 100 & 10,0 & الاجتماعية \\
\hline.. .1 & $r, \wedge 97$ & صفر & 00 & 0,0 & 100 & 10,0 & السلوك البيئي \\
\hline$\ldots \ldots$ & $r, \wedge .$. & ضفر & 00 & 0,0 & 100 & 10,0 & الدرجة الكلية \\
\hline
\end{tabular}

أنشارت نتائج جدول ( §) إلى وجود فروق دالة احصائيا بين منوسطات رتب درجات المجموعتين التجريبيـة والضـابطة علي مقياس السلوكيات البيئيـة الايجابيـة(المعارف البيئيـة، والبيئة الاجتماعية، والسلوك البيئي، والدرجة الكلية) في القياس بعد تطبيق البرنامج؛ وذلك في اتجاه المجموعة التجريبية.

ممـا يشـير إلـى فعاليـة البرنـامج المسـتخدم فـى الدراســة و ترجـع هـذه الفـروق إلى ان

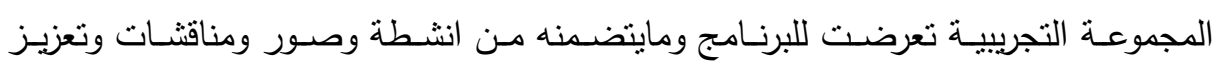

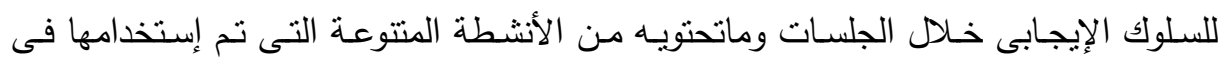
البرنامج لتحسين السلوك البيئى والتى تحتوى على معلومات عن أضـرار التدخين و أضرار استخدام المبيدات الحشرية و آنار ذللك على صحة الإنسان بشكل عام وعلى الأطفال بشكل

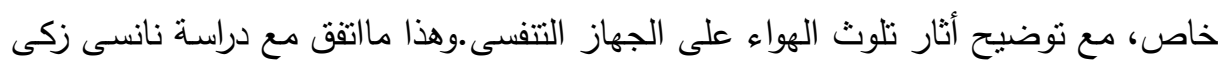

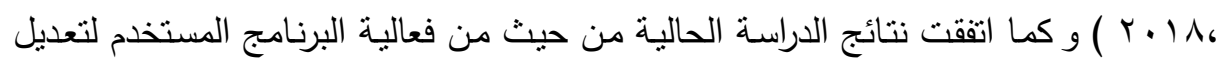

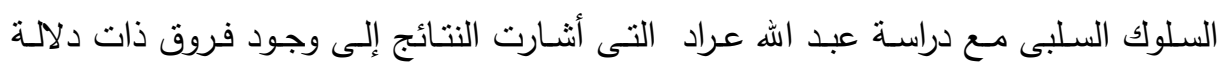


مجلة العلوم البيئية

معهد الدراسات والبحوث البيئية - جامعة عين شمس لئه

رضا محمد محمود طنطاوى وآخرون

إحصـائية بـين منوسطى رتب درجـات المجـوعتين الضـابطة والتجريبيـة لصـالح المجموعـة

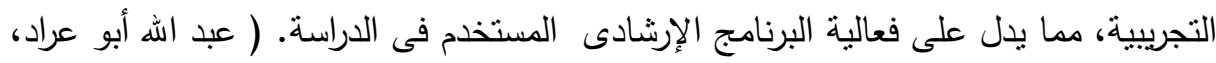

وتمثل إستراتيجيات البرنامج عنصر اساسى فى نجاح البرنامج، مثل النقاش المفتوح،

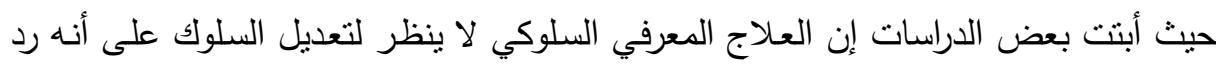

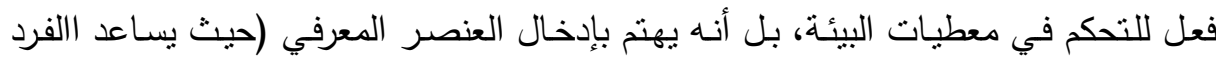

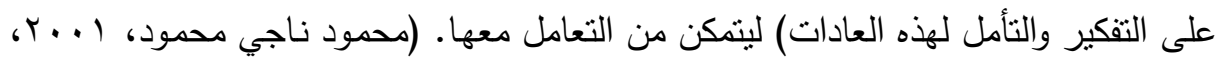

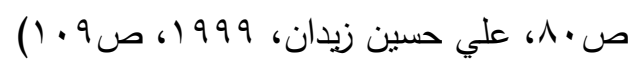

نتائج الفرض الثاني: ينص على "توجد فروق داله إحصائيا بين متوسطات رتب درجات

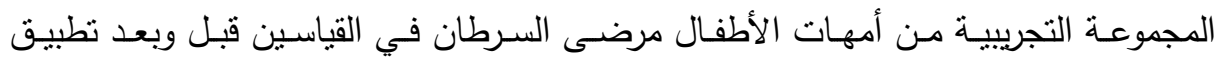
البرنامج على مقياس السلوكيات البيئية الايجابية وذلك في اتجاه القياس البعدي". وللتأكد من صدق هذا الفرض حسبت الباحثون اختبار (ويلكوكسون) اللابارامتري لدلالة الفروق بين المجموعات المرتبطة، ويوضح ذلك جدول( ه ه ). متوسطات الرتب ومجموعها وقيم (Z W) ودلالتها بين القياسين قبل وبعد البرنامج للمجموعة التجريبية(ن= • (1) على مقياس السلوكيات البيئية الايجابية

\begin{tabular}{|c|c|c|c|c|c|c|c|}
\hline \multirow{2}{*}{ مستوى الدلالة } & \multirow[b]{2}{*}{ "Z" قيمة } & \multirow[b]{2}{*}{ "W" قيمة } & \multicolumn{2}{|c|}{ قياس بعدي } & \multicolumn{2}{|c|}{ قياس قبلي } & \multirow{2}{*}{ القياس } \\
\hline & & & مجموع & متوسط & مجموع & متوسط & \\
\hline$\cdot 6 \cdot 1$ & $r, \lambda r$. & صفر & 00 & 0,0 & صفر & صفر & المعارف \\
\hline$\cdot 6 \cdot 1$ & $r, \wedge \leq Y$ & صفر & 00 & 0,0 & صفر & صفر & الاجنماعية \\
\hline$\cdot 6 \cdot 1$ & $r, \lambda \leq \wedge$ & صفر & 00 & 0,0 & صفر & صفر & البلوكي \\
\hline$\cdot 6+1$ & r,Aro & صفر & 00 & 0,0 & صفر & صفر & الدلية \\
\hline
\end{tabular}

$$
\text { المجلد التاسع والأربعون، العدد الثاني عشر ، جزء (0) ديسمبر ·.r. }
$$
الترقيم الدولي 
أنثارت نتائج جدول ( 0) إلى وجود فروق دالة إحصائيا بين متوسطات رتب درجات

المجموعـة التجريبيـة مـن أمهات الأطفال مرضـى السـرطان علـي مقيـاس السـلوكيات البيئيـة الايجابية(المعارف البيئية، والبيئة الاجتماعية، والسلوك البيئي، والدرجة الكلية) في القياسين قبل وبعد نطبيق البرنامج وذلك في اتجاه القياس البعدى، و يمكن تفسير نتيجة هذا الفرض ولئه

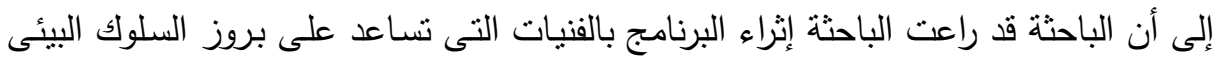

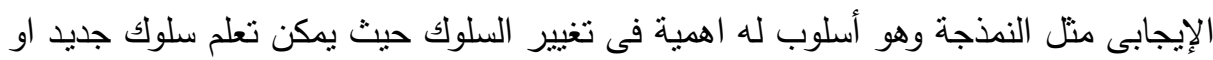

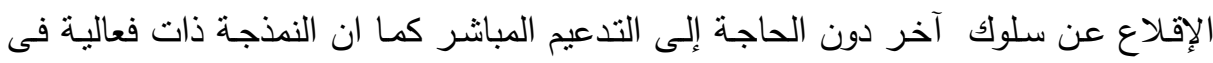

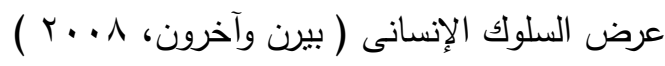
وفى هذا الإطار قامت الباحثة بعرض صور متسلسلة لطريقة غسل اليدين ثم توضيح

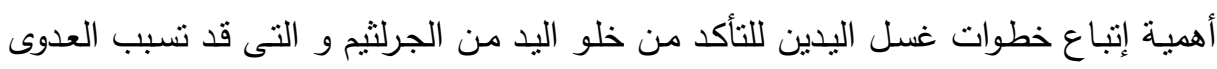

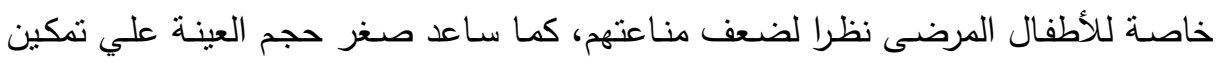

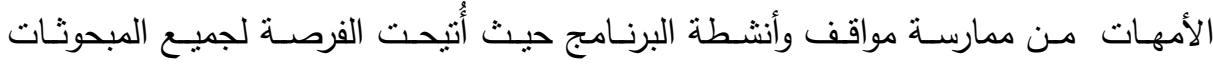

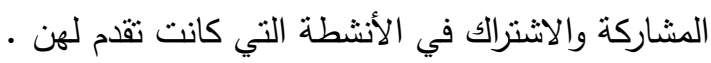
نتـائج الفـرض الثالـث: ينص على "لا توجد فروق داله إحصـائيا بين متوسطات رتب التب

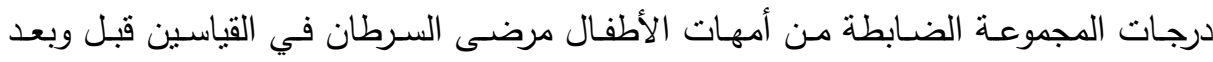

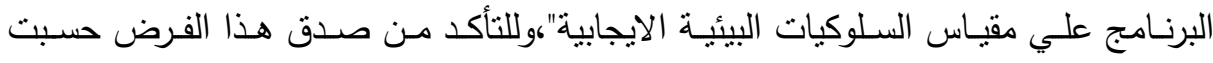
الباحثون اختبار (ويلكوكسون) اللابارامتري لدلالة الفروق بين المجموعات المرتبطة، ويوضح 
مجلة العلوم البيئية

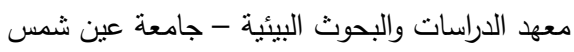

رضا محمد محمود طنطاوى وآخرون

متوسطات الرتب ومجموعها وقيم (Z W) ودلالتها بين القياسين قبل وبعد البرنامج للمجموعة الضابطة(ن= • 1) على مقياس السلوكيات البيئية الايجابية

\begin{tabular}{|c|c|c|c|c|c|c|c|}
\hline \multirow[b]{2}{*}{ مستوى الدلالة } & \multirow[b]{2}{*}{ "Z" قيمة } & \multirow[b]{2}{*}{ قيمة "W" } & \multicolumn{2}{|c|}{ قياس بعدي } & \multicolumn{2}{|c|}{ قياس قبلي } & |القياس \\
\hline & & & رجموع & متوسط & مجموع & متوسط & \\
\hline غير دالة & $\cdot, \wedge \vee 9$ & 9 & 19 & $\varepsilon, V_{0}$ & 9 & $r$ & المعارف البيئية \\
\hline غير دالة & $\cdot, V \cdot V$ & 0 & 0 & $r, 0$ & 1. & r, & $\begin{array}{c}\text { الاجنماعية } \\
\text { البيئة }\end{array}$ \\
\hline غير دالة & . TYY & 9 & ir & $\varepsilon$ & 9 & $r$ & السلوك البيئي \\
\hline غير دالة & . 779 & iv & $r \wedge$ & $\mathrm{v}$ & IV & $r, \varepsilon$ & الدرجة الكلية \\
\hline
\end{tabular}

أشارت نتائج جدول (†) إلى عدم وجود فروق دالة إحصائيا بين متوسطات رتب درجات

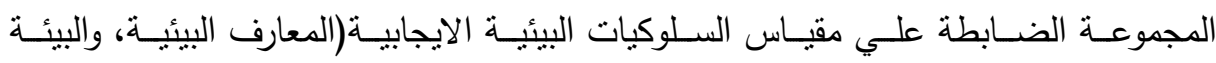
الاجتماعية، والسلوك البيئي، والدرجة الكلية) في القياسين قبل وبعد البرنامج، وترجع صحة

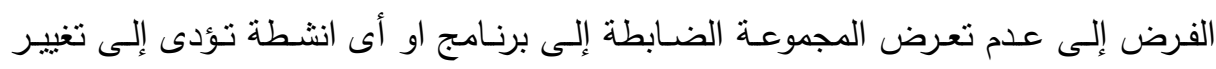

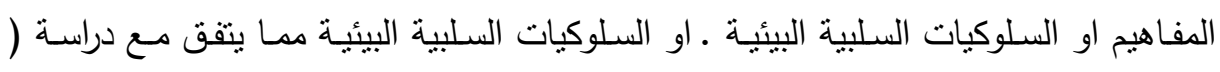

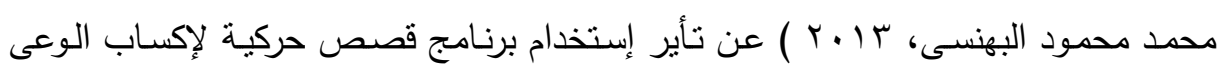

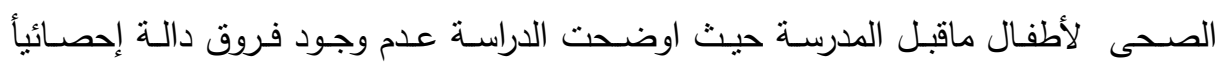
للمجموعة الضابطة على محاور الوعى الصحى نتيجة لعدم تعرضهم للبرنامج موضع الدراسة،

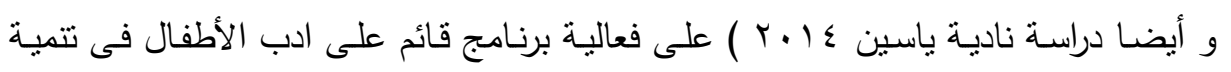

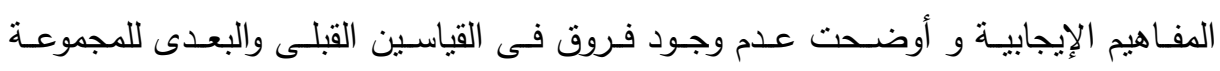

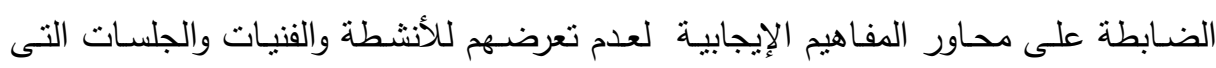
• بتضمنها البرنامج

$$
\begin{aligned}
& \text { r.r. المجلد التاسع والأربعون، العدد الثاني عشر، جزء (0) ديسمبر } \\
& \text { التزقيم الدولي 0826-1110 الاني }
\end{aligned}
$$


نتائج الفرض الرابع: ينص على "لا نوجد فروق داله إحصائيا بين متوسطات رتب درجات المجموعة التجريبية من أمهات الأطفال مرضى السرطان في القياسين البعدي والتتبعي لنطبيق البرنامج على مقياس السلوكيات البيئية الايجابية".

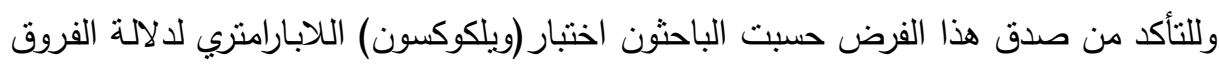
بين المجموعات المرنبطة، ويوضح ذلك جدول( V ) ). منوسطات الرثب ومجموعها وقيم (Z W) ودلالتها بين القياسين البعدي والتتبعي لتطبيق البرنامج للمجموعة التجريبية(ن= • ( ) على مقياس السلوكيات البيئية الايجابية

\begin{tabular}{|r|r|r|r|r|r|r|r||}
\hline & & & \\
\hline
\end{tabular}

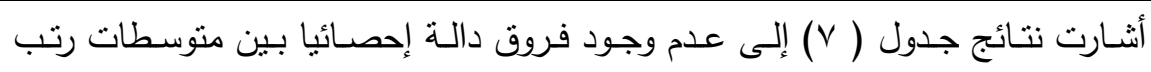
درجات المجموعة التجريبية علي مقياس السلوكيات البيئية الايجابية(المعارف البيئية، والبيئة الاجتماعية، والسلوك البيئي، والدرجة الكلية) في القياسين البعدي والتتبعي لتطبيق البرنامج.

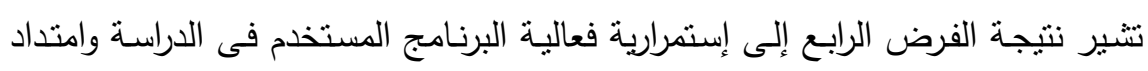

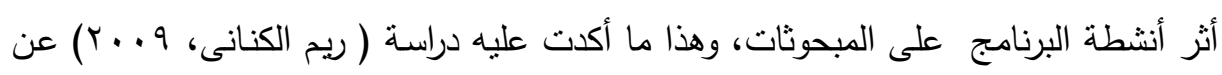

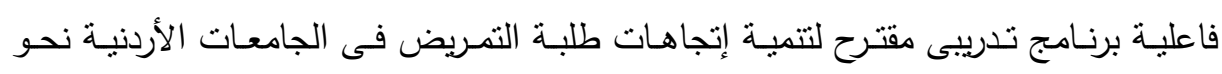

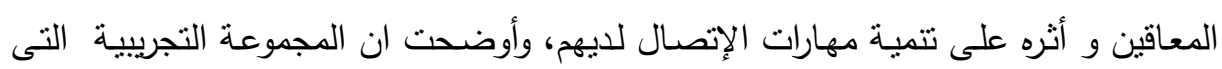

$$
\begin{aligned}
& \text { r.r. المجلد التاسع والأربعون، العدد الثاني عشر، جزء (0) ديسمبر } \\
& \text { التزقيم الدولي 0826-08 1110 }
\end{aligned}
$$


تعرضـت للبرنـامج و ماتحتويـه مـن أنشـة مازالت تحنفظ بـنفس السـلوكيات الإيجابيـة نحـو المعاقين

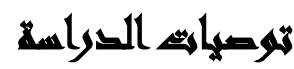

ا ـ تتمية الوعى البيئى لدى المرأة بشكل عام والتعريف بمخاطر ممارسة السلوكيات البيئية

$$
\text { ضد البيئة . }
$$

r. تفعيل البعد البيئى فى دور هيئة التمريض لما تتمتع به من مهارات الإتصال مع المرضى

$$
\text { و ذوبهم }
$$

r. العمل على وضع خطط إستراتيجية للحد من التلوث البيئى . ـ. تبنى وضع إستراتيجية نشر الوعى البيئى فى المنشآت الصحية . هـ التعريف لمخاطر التلوث ومسبباته وإرتباط التلوث بالأضرار الصحية و إنتشار الأمراض ج. توعية امهات وأهالى المرضى بخطورة التلوث البئى الناتج عن الممارسات السلوكية · السلبية لأفراد المجتمع V. عمل برامج توعية منتوعة ومناسبة لجميع الفئات، وتشمل اسباب التلوث البيئى وأضراره وأنواعه وكيفية السيطرة عليه من خلال وضع آلية للحد من التلوث البيئى . ^. وضع خطط متكاملة بين وزرارتى الصحة وشئون البيئة لمعالجة المشكلات البيئية فى المنشآت الصحية للحد من التلوث البيئة. 9. تفعيل البعد البيئى فى المناهج الدراسية لتتمية التربية البيئية لدى الأطفال، وتغيير الثقافة البيئية الموروثنة. • 1 ـ تحسين الخدمات الصحي ف المستشفيات العامة بحيث لاتكتفى على الرعاية الصحية فقط بل تتسع لنتمل التوعية الصحية مقترنة بالتوعية البيئية .

$$
\begin{aligned}
& \text { المجلد التاسع والأربعون، العدد الثاني عشر، جزء (0) ديسمبر • r.r } \\
& \text { الترقيم الدولي }
\end{aligned}
$$




\section{المراني}

إبراهيم الدر فريد، (ع 9 (1) :الأسس البيولوجيو لسلوك الإنسان، بيروت : الدار العربية .

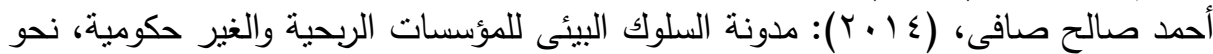

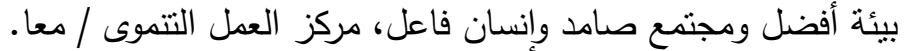

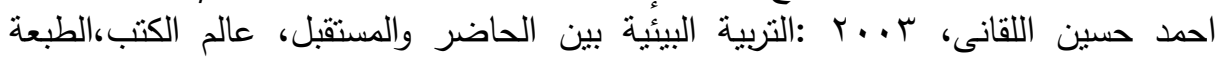
الثانية.

أسماء محمد إبراهيم، ( • ( ب ) ): تقويم خدمات الرعاية الإجتماعية للأطفال مرضى السرطان

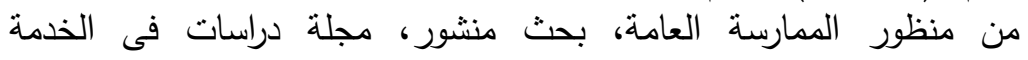
الإجتماعية والعلوم الإنسانية، مصر العنة

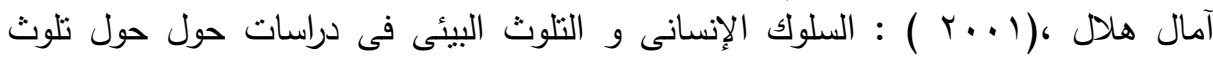

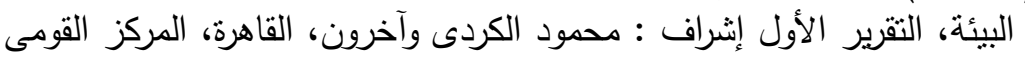

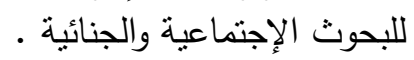

جمال الخطيب، ( • (199) .تعديل السلوك : القوانين والإجراءة الإت، الرياض : مكتبة الصفحات

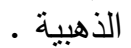

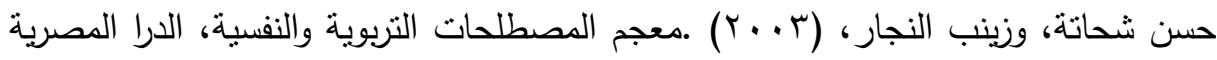
اللبنانية.

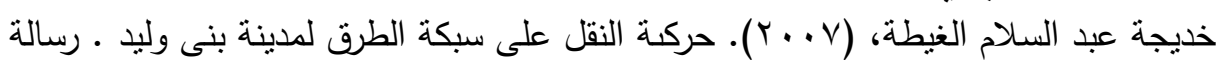
ماجستر كليبيا: جامعة المرقب.

رشيد حمد الحمد، محمد سعيد الصبارينى، (ـ99 (199)، البيئة ومشكلاتها، علم المعرفة سمكتبة

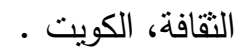

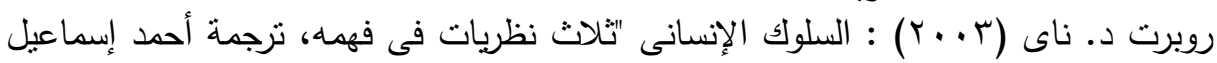

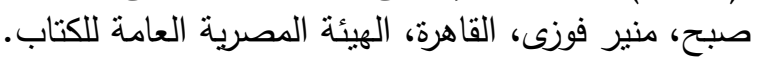

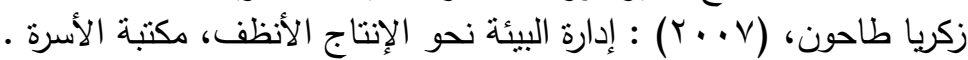

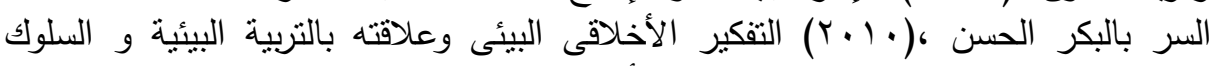

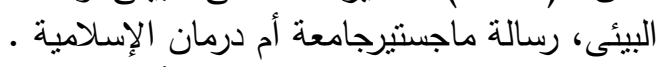

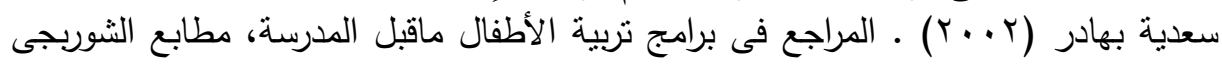

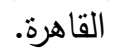

$$
\begin{aligned}
& \text { r.r. المجلد التاسع والأربعون، العدد الثاني عثر، جزء (0) ديسمبر }
\end{aligned}
$$

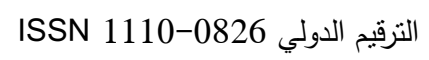




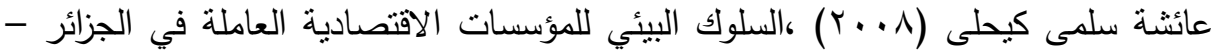

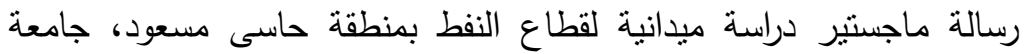

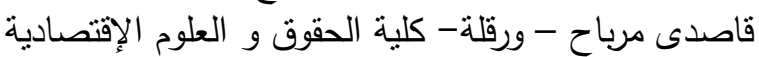

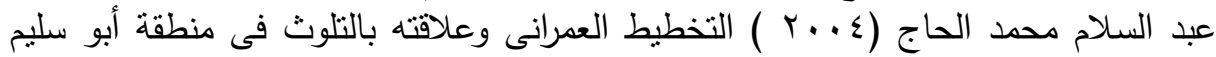
بطرابلس إن إن

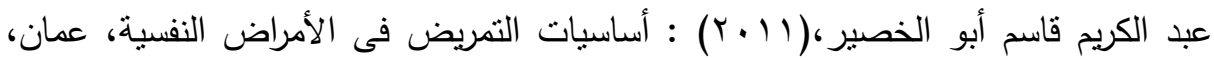

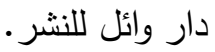

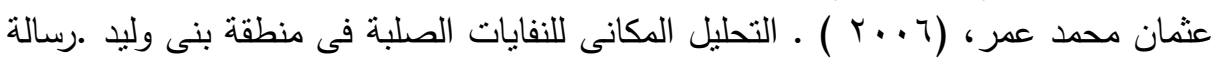

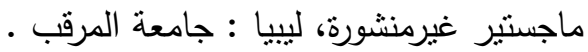

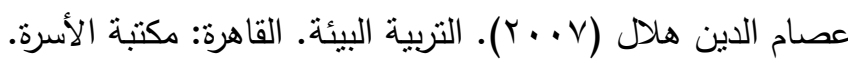

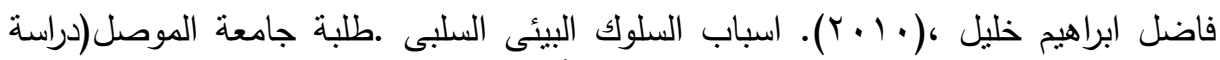

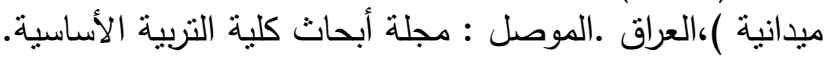

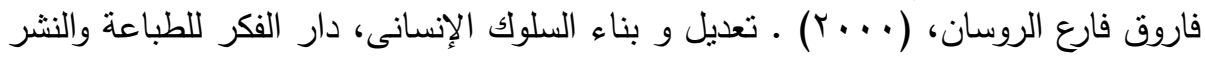

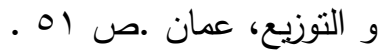

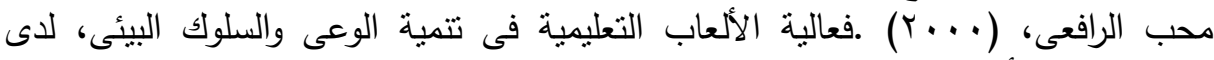

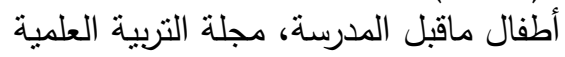

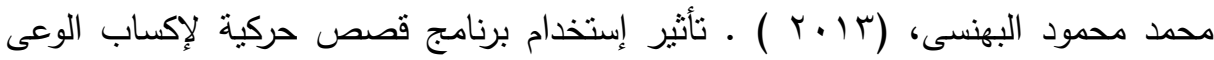

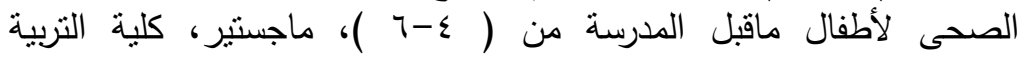

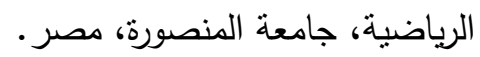

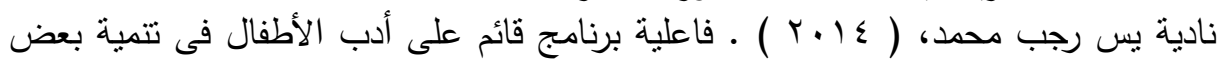

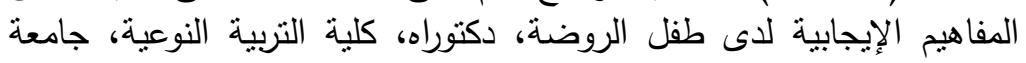

(Deutch Merton ,Robert, M. Krauss ,(1995). Theories in social psychology, Basics Books (Inc. Library of congress Card.

Budak, Dilek Boston, Budak, Fuat, Zaimo lu ,Zeynep , Kekec , Secil and Sucu, M.Yavuz. (2005). Behaviour and Attitudes of Students Towards Environmental Issues at Faculty of Agriculture, Turkey.

David Mechanic, (1978): Medical Sociology, (2nd Edition, The free Press, New York.

$$
\begin{aligned}
& \text { r.r. المجلد التاسع والأربعون، العدد الثاني عشر ، جزء (0) ديسمبر } \\
& \text { الترقيم الدولي 0826-1110 }
\end{aligned}
$$




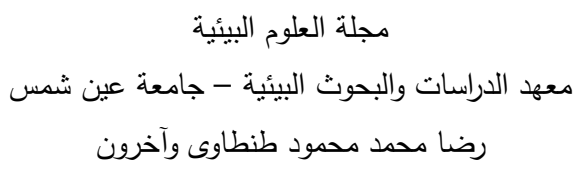

Gelntis \&et. Al(2004): Division of the environmental, University of tronto Canada Avelable,

Kaiser \& ET. Al (1999): Ecological Behaviors Dependency on deferent form of knowledge. Applied psychology: An International review.

\title{
THE ROLE OF NURSING STAFF IN IMPROVING ENVIRONMENTAL OF MOTHERS CHILD WITH \\ CANCER
}

\author{
Reda M. M.Tantawy ${ }^{(1)}$ Mohamed R. Elbehairy ${ }^{(2)}$ \\ Madiha A. Morsy ${ }^{(3)}$ Al shaimaa B. A. gad ${ }^{(4)}$
}

1) Hospital 57357 2) Childhood Graduate Studies College, Ain Shams University 3) Faculty of Nursing, Children , Ain Shams University 4) Institute of Environmental Studies and Research, Ain Shams University

\begin{abstract}
In view of the dynamic interaction between the environment and mankind, and that all human actions affect the environment negatively or positively, and in order to preserve the environment and its resources from being depleted for the sake of future generations, we must develop positive behavior through the individual and the family, and given the existence of a positive and close relationship between environmental pollution and diseases and pollution. Environmentalism is nothing but the product of negative environmental behaviors. Therefore, the current study aimed to improve the environmental behavior of mothers of children with cancer and residents for a period of not less than a month inside the hospital, and the study used the experimental method and the
\end{abstract}

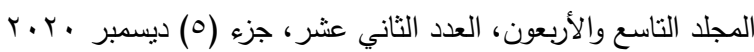

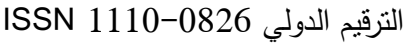




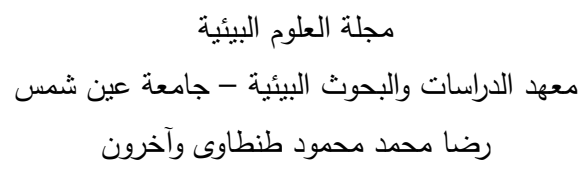

study sample $(\mathrm{n}=20)$ was divided equally into two control and experimental groups.

The study tools were based on the Environmental Behavior Scale (the researcher's preparation), the economic, social and cultural level scale, and the intelligence test for Raven. The researcher also relied on the Behavior Modification Program (Researcher Preparation), which contains a set of activities, pictures and videos in addition to the techniques and strategies of the program. The implementation of the program took two months. The study found that there are statistically significant differences between the control and experimental groups after applying the program in favor of the experimental group, which indicates the effectiveness of the program for improving environmental behavior in addition to activating the environmental dimension in the nursing homes towards patients and their families.

The recommendations of the study were to activate the role of nursing towards the environment and to generalize the program for improving environmental behavior in public hospitals and all health facilities to contribute to relieving the burden of the environment and an attempt to conserve environmental resources, raising environmental awareness among hospital residents from patients and their families.

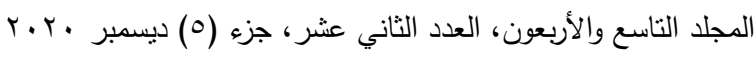

$$
\begin{aligned}
& \text { الترقيم الدولي 0826-1110 }
\end{aligned}
$$

